\title{
NARRATIVAS FANTÁSTICAS E LETRAMENTO LITERÁRIO: A FORMAÇÃO DO JOVEM LEITOR
}

\section{LAIO HENRIQUE DE OLIVEIRA}

\author{
Profa. Dra. Érika Kelmer Mathias
}

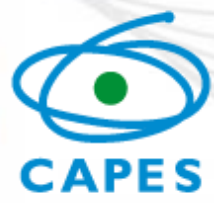




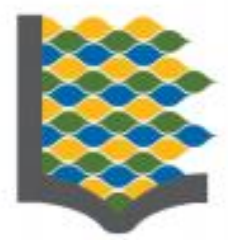

Oliveira, Laio Henrique de Oliveira.

Narrativas fantásticas e letramento literário : A formação do jovem leitor / Laio Henrique de Oliveira Oliveira. -- 2021.

$68 \mathrm{f}$.

Orientador: Érika Kelmer Mathias Mathias

Dissertação (mestrado profissional) - Universidade Federal de Juiz de Fora, Faculdade de Letras. Programa de Pós-Graduação em Letras, 2021.

1. Formação do leitor. 2. Letramento literário. 3. Narrativa fantástica. I. Mathias, Érika Kelmer Mathias, orient. II. Título. 


\section{FICHA TÉCNICA}

\section{Organizadores}

\section{Elza de Sá Nogueira}

Érika Kelmer Mathias

José Carlos Gonçalves

Luciana Teixeira

Lucilene Hotz Bronzato

Marco Aurélio de Sousa Mendes

Natália Sathler Sigiliano

Patrícia Pedrosa Botelho

Thais Fernandes Sampaio 


\section{APRESENTAÇÃo DA COLEÇÃo}

A necessidade de se repensar a educação, como forma de alteração positiva de realidades, cria também uma exigência de se estabelecerem caminhos que reinventem o processo de formação docente. Nesse contexto, o PROFLETRAS - Mestrado Profissional em Letras, erigido sob indução da CAPES - reúne hoje 49 (quarenta e nove) Instituições Associadas (IA) de todas as regiões do país e tem cumprido uma agenda pedagógica relevante nos processos de formação continuada de professores e, de maneira especial, na mudança de realidade da educação brasileira. Isso porque o programa tem o grande diferencial de ser voltado exclusivamente para professores de português que estão efetivamente atuando na rede pública de ensino e, além disso, tem como Trabalho de Conclusão Final (TCFs) uma proposta de natureza necessariamente interventiva.

A Universidade Federal de Juiz de Fora (Faculdade de Letras em parceria com o Colégio de Aplicação João XXIII) se constitui como uma IA nesse Programa e, buscando enfrentar o desafio de uma escola contemporânea ao século XXI, propõe uma nova coleção de Cadernos Pedagógicos Digitais, por meio dos quais são apresentados os TCFs de sua terceira turma. Na coleção aqui apresentada, cada um dos doze Cadernos descreve o trabalho interventivo desenvolvido por um professor-pesquisador, sob orientação de um docente do Programa. Cada Caderno se faz acompanhar ainda de um documento com a fundamentação teórico-metodológica adotada e a análise da proposta desenvolvida.

As propostas de intervenção apresentadas são múltiplas e envolvem diferentes aspectos dos processos de ensino e aprendizagem de Língua Portuguesa. Seja focalizando os processos de letramento literário, as estratégias de ressignificação das práticas interacionais, a proposição de novas práticas para a leitura e escrita de gêneros, perpassando questões sobre análise linguística, ou mesmo a inserção de novas tecnologias digitais no ensino, todos os trabalhos procuram responder à meta do PROFLETRAS de se tornar um espaço para o desenvolvimento de pedagogias que efetivem a proficiência em letramentos dos alunos que cursam os nove anos do ensino fundamental. 
Ao inovar no formato do trabalho de conclusão dos mestres que está formando, o PROFLETRAS/UFJF sinaliza duas preocupações importantes. Primeiro, desejamos que 0 conhecimento aqui produzido circule do modo mais fácil e democrático possível. A ambição é que, através da ampla divulgação desses trabalhos de conclusão, provoquemos mudanças não apenas na prática pedagógica dos professores que formamos, mas que as ideias aqui plantadas possam gerar mudanças também no ensino de Língua Portuguesa realizado diariamente em inúmeras salas de aula de todo o país.

Ademais, a criação de um Caderno Pedagógico Digital traz ainda a economia de milhares de folhas de papel - uma boa lição a ser repassada por professores-pesquisadores da escola fundamental.

Portanto, da mesma forma como a elaboração destes trabalhos exigiu ressignificação das práticas de salas de aulas reais, esperamos que este caderno ofereça a você, leitor, novos olhares e novas perspectivas para o ensino de língua portuguesa. 


\title{
APRESENTAÇÃO DO PROJETO
}

\author{
Caro Professor e Cara Professora,
}

Este Caderno Pedagógico apresenta algumas propostas como forma de desenvolver os pressupostos do letramento literário no espaço escolar de modo que o aluno possa se apropriar, no sentido de tornar sua, a linguagem literária. É com esse objetivo que produzimos esta proposta de intervenção a ser desenvolvida em uma turma de $7^{\circ}$ ano, do Ensino Fundamental II, envolvendo a ampliação do repertório de leitura de contos fantásticos: narrativas curtas que provocam a hesitação do leitor que, diante de um acontecimento insólito, busca explicações em duas lógicas distintas: uma conforme as leis do mundo natural; outra, conforme leis sobrenaturais. Sugerimos ao professor conhecer a obra "Introdução à literatura fantástica", de Tzvetan Todorov (2008), publicada pela editora Perspectiva.

Assim, de forma a ampliar o repertório literário dos alunos, elaboramos a proposta de intervenção, que se encontra organizada em quatro etapas. A primeira delas diz respeito à motivação para a leitura; a segunda se refere à leitura mediada do conto "Crianças à venda. Tratar aqui", de Rosa Amanda Strausz; a terceira etapa consta da sistematização do gênero fantástico; por fim, a quarta etapa diz respeito à avaliação do processo de leitura.

$\mathrm{Na}$ etapa 1, composta por um momento de motivação para a leitura do conto, propomos a análise dos elementos verbais e visuais da capa do livro "Sete ossos e uma maldição" de Rosa Amanda Strausz. Este momento é importante para que o aluno comece a estabelecer alguns pactos e projeções sobre a leitura. A compreensão da visualidade da capa permitirá que o aluno perceba os efeitos de sentido das cores e das perspectivas da imagem de forma a criar efeitos de medo e mistério.

$\mathrm{Na}$ etapa 2, buscamos desenvolver a proposta de leitura do conto por meio de duas estratégias, a saber, a leitura protocolada e as dinâmicas de leitura. A leitura protocolada visa estabelecer a mediação da leitura pelo professor e o compartilhamento das interpretações pelos alunos. As dinâmicas são formas alternativas de leitura do conto e podem ser desenvolvidas durante a leitura protocolada em momentos específicos. Cabe destacar que as questões elaboradas para a leitura podem ser adaptadas à realidade de cada turma, sem a necessidade de serem todas elas desenvolvidas com os alunos. 
Na terceira etapa, propomos a sistematização do gênero fantástico. Para tal, buscamos estabelecer algumas comparações com o gênero maravilhoso, de modo a trazer as experiências de leitura que o alunos já possuem, em direção a um conhecimento novo sobre outros tipos de narrativa, no caso as narrativas fantásticas. Neste momento, retomamos algumas passagens do conto para pontuar as marcas características do gênero, como a hesitação e a incerteza, e como elas são engendradas na construção do texto por meio das modalizações e formas verbais do imperfeito.

Por fim, na quarta etapa, trazemos algumas propostas de avaliação da leitura para que se possa verificar a ampliação de repertório literário que os alunos adquiriram durante a experiência da leitura do conto fantástico. Cada professor deve fazer as adequações necessárias conforme sua realidade escolar e o contexto de cada turma.

Desejamos um bom trabalho a você, professor, e esperamos contribuir para que suas práticas de ensino sejam cada vez mais transformadoras.

\section{BAIXAR DISSERTACÃO}




\section{SUMÁRIO}

ETAPA 1 - MOTIVAÇÃO

Momento 1: Leitura da capa do livro "Sete ossos e uma maldição". - p. 9

ETAPA 2 - LEITURA DO CONTO

Momento 1: Leitura protocolada do conto "Crianças à venda. Tratar aqui". - p. 11 Momento 2: Dinâmicas de leitura. - p. 24

ETAPA 3 - SISTEMATIZAÇÃO

Momento 1: Características do gênero fantástico. - p. 42

ETAPA 4 - AVALIAÇÃO

Momento 1: Propostas de avalição. - p. 45 


\section{MOTIVAÇÃO: LEITURA DA CAPA DO LIVRO "SETE OSSOS E UMA MALDIÇÃO"}

\section{1 momento}

Este momento busca motivar os alunos, de forma a criar expectativas de leitura para o conto, por meio da leitura da imagem que compõe a capa do livro "Sete ossos e uma maldição", bem como discutir sobre os outros elementos da capa, como o título, e apresentar a autora, editora e projeto gráfico. Sugerimos ao professor projetar a imagem editada, somente com a ilustração e comentar que se trata da capa de um livro. Feito isso, sugerimos a discussão abaixo:

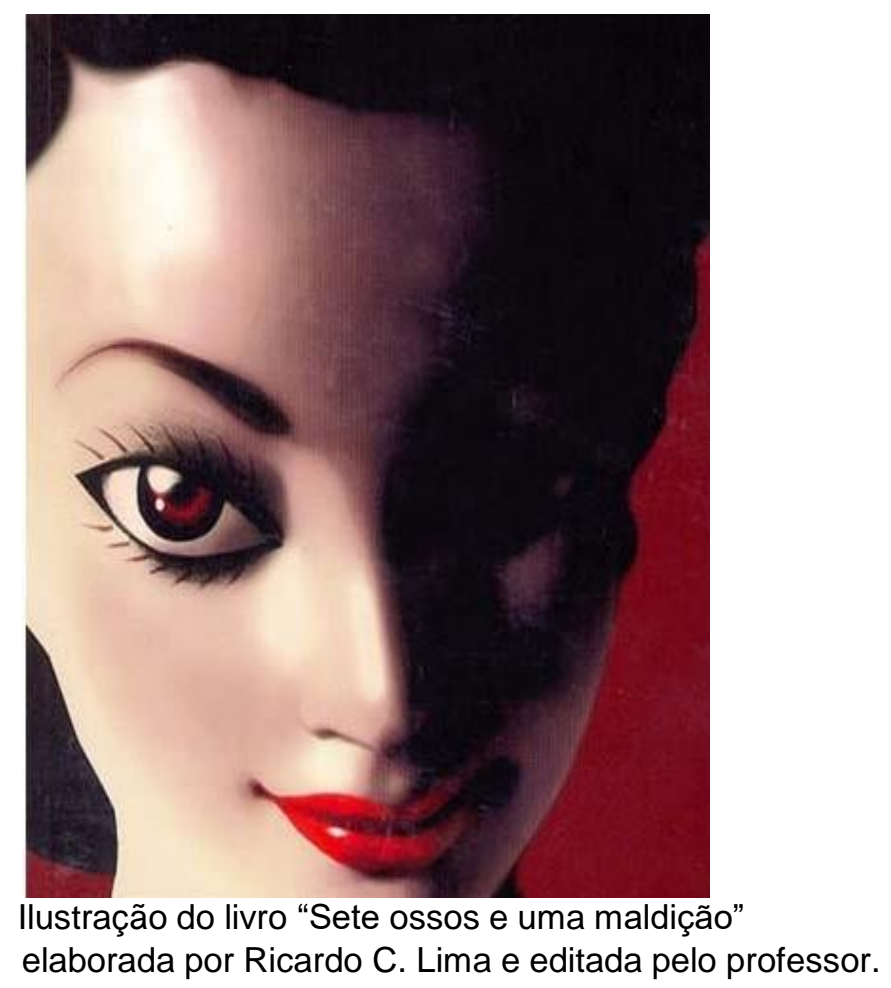

Sugerimos ao professor iniciar a leitura da capa com questões do tipo:

1. O que vocês veem nessa imagem?

2. O que está mais destacado neste rosto?

2. Pensando na incidência da luz sobre o rosto na imagem, o que é mostrado?

3. O que pode significar o que a imagem não mostra?

4. Quais cores mais se destacam na imagem?

5. O que essas cores podem significar nessa imagem?

7. Qual seria o título deste livro?

Após a leitura da imagem, o professor poderá fazer a projeção da capa do livro, constando, agora, a imagem e o título dele, como se observa a seguir: 


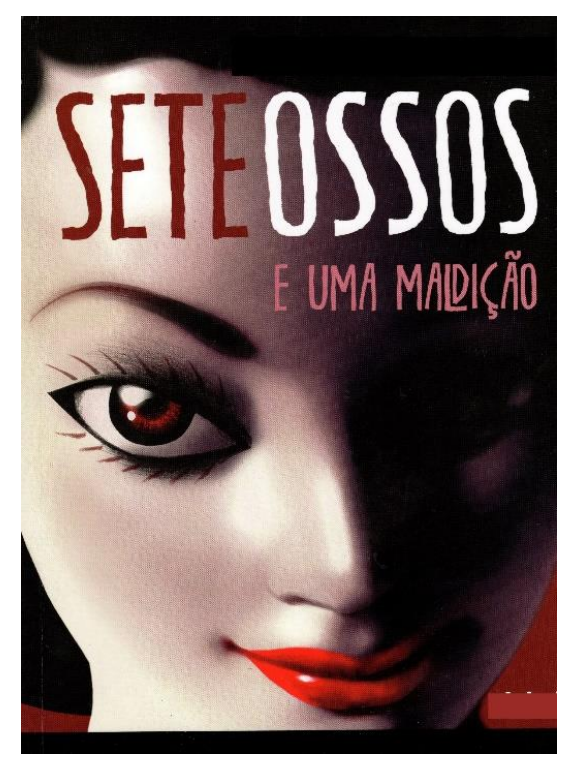

Ilustração do livro "Sete ossos e uma maldição"

elaborada por Ricardo C. Lima e editada pelo professor,

Sugerimos que o professor continue a discussão inicial, chamando a atenção dos alunos para as palavras que compõem o título, com questões do tipo:

1. A palavra "ossos" pode remeter a quê?

2. Qual o significado da palavra "maldição"?

3. Em que outros contextos o número "sete" é significativo? E a que este número se refere nestes contextos?

4. Que tipo de histórias vocês acham que este livro narra?

5. Como se trata de uma capa de livro, que outros elementos estão faltando?

Sugerimos ao professor projetar, neste momento, a capa do livro na íntegra:

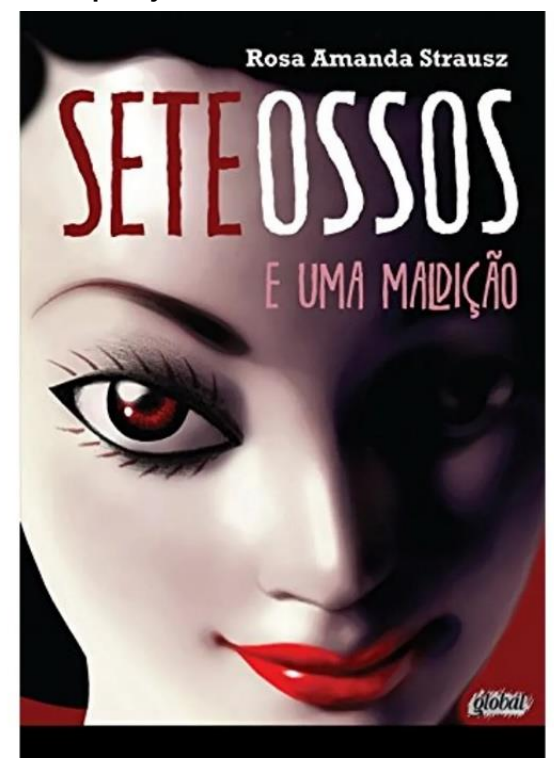

Capa do livro "Sete ossos e uma maldição" projeto gráfico de Ricardo Cunha Lima

e apresentar ao alunos a biografia da autora. É interessante comentar também sobre o processo de edição do livro, ilustração, e apresentar os dados bibliográficos. Sugerimos, por fim, deixar que o livro percorra a sala, para que os alunos possam folheá-lo e conhecê-lo. Após isso, explicar aos aluno que faremos a leitura de um dos contos do livro. 


\section{Etapa 1: leitura do conto "Crianças à venda. Tratar aquil"}

Nesta etapa, trabalhamos com duas estratégias para promover a leitura do conto “Crianças à venda. Tratar aqui” (STRAUSZ, 2013, p. 7-17). A primeira delas é uma forma de leitura protocolada, em que fragmentamos o conto em 41 trechos, a fim de promover uma discussão bastante mediada de cada parte do texto. Os trechos recortados estão sequenciados, conforme a ordem em que aparecem no livro e, por isso, não referenciamos cada fragmento. Para cada trecho, elaboramos questões, sempre numeradas a partir de 1, que perpassam o mapeamento do texto, a construção de inferências e a elaboração de hipóteses. A divisão do conto em trechos específicos visa reforçar a prática de elaboração de hipóteses e sequenciar a leitura por meio da confirmação das hipóteses elaboradas. A segunda estratégia busca promover ações em momentos específicos do conto, por meio de dinâmicas de leitura. Estas dinâmicas são alternativas de leitura que podem ser desenvolvidas concomitantemente à primeira estratégia. Cabe a cada professor decidir fazer somente a leitura protocolada ou inserir nesse processo as ações das dinâmicas. Ao todo, elaboramos sete dinâmicas que visam promover a escrita literária dos alunos, a performatividade de cenas e a prática de elaboração de hipóteses. Estas dinâmicas são apresentadas ao final, indicando os trechos a que correspondem. Apresentamos, a seguir, a proposta de leitura protocolada. Sugerimos ao professor fazer a entrega dos trechos, um a cada vez, e, assim, ir mediando as questões com os alunos.

Objetivos: Promover uma leitura mediada do conto selecionado, a fim de promover a experiência de leitura, de modo a dar relevo para os aspectos constitutivos do fantástico, a saber: ambiguidades, hesitações e incertezas, no que diz respeito à natureza do evento narrado.

Leitura protocolada do conto:

\section{Trecho 1}

Todos disseram que Marialva era louca e desalmada quando ela pôs os filhos à venda.

1. Quem são os personagens apresentados até agora na narrativa?

2. O que nós sabemos de Marialva?

3. Além dos personagens citados, podemos dizer que há outros que fazem parte dessa história?

4. Por que vocês acham que Marialva pôs os filhos à venda?

5. Vocês acham que Marialva vai conseguir vender todos os filhos?

\section{Trecho 2}

Até o padre tentou demovê-la de ideia tão cruel. Mas nada adiantou. A mulher era obstinada. "Quero que eles tenham um futuro melhor que o meu", ela repetia.

1. Qual novo personagem aparece na história?

2. O texto nos dá mais alguma informação sobre Marialva?

3. Observando a fala da personagem, podemos dizer que a vida de Marialva é boa ou ruim?

4. Como vocês imaginam ser a vida de Marialva?

5. Quantos filhos vocês acham que Marialva tem? 


\section{Trecho 3}

Olhando bem para o lugar, quem poderia condená-la? Um casebre miserável, perdido numa curva do rio, sem eletricidade, sem comida, sem dinheiro, sem remédio, sem nada por perto. Tinha parido nove filhos. Só restavam cinco quando decidiu vendê-los.

1. Quantos filhos Marialva teve?

2. E quantos filhos Marialva tem agora?

3. Como era o lugar em que ela vivia com os filhos?

4. Este lugar fica perto ou longe da cidade?

5. Vocês acham que os filhos de Marialva morreram por qual motivo?

6. Dos filhos que ficaram, vocês acham que ela já vendeu algum?

\section{Trecho 4}

Não queria mais ver criança morrendo de fome e doença em seus braços sem que pudesse fazer nada para impedir.

O primeiro a partir foi Tião, levado por uma família americana.

1. O que podemos confirmar sobre a morte dos filhos?

2. O que Marialva fazia para impedir que isso acontecesse?

3. Qual novo personagem aparece na história e o que sabemos sobre ele?

4. Diante da impossibilidade de criar os filhos, Marialva toma a atitude de vendê-los. $O$ que isso demonstra em relação ao que ela sente pelos filhos?

5. Como vocês acham que Marialva vai ficar após vivenciar essa situação?

6. Vocês acham que a vida de Tião vai melhorar ou piorar?

\section{Trecho 5}

Um mês depois da viagem, chegou carta com foto do menino, limpo e sorridente, bem vestido e já mais gordinho, no meio de brinquedos e livros novos, e abraçado a seus novos pais. Marialva enxugou as lágrimas e teve certeza de que fazia a coisa certa.

1. Como está a vida de Tião agora?

2. Como Marialva se sente após vender o filho?

3. Vocês acham que Marialva continuará vendendo os outros filhos?

4. Se sim, para onde vocês acham que eles irão?

\section{Trecho 6}

Em seguida, foram Francineide, para o Rio de Janeiro, e Ronivon, para Curitiba.

Com o dinheiro da venda dos três, Marialva comprou uma cabra, três galinhas, um cobertor para as noites frias, sabão de tomar banho e uma panela nova.

O seguinte seria Fabiojunio, que já estava encomendado por uma família que vivia em Cruz Alta, uma cidade próxima. O casal chegaria dali a dois dias e Marialva se esforçava para dar banho no menino e torná-lo mais apresentável.

1. O que Marialva fez com o dinheiro da venda dos filhos?

2. Quais são os novos personagens que conhecemos agora e o que sabemos sobre eles?

3. Tendo em vista o que Marialva compra com a venda dos três filhos, o que podemos dizer sobre o valor da negociação?

4. O que Marialva queria ao tentar tornar Fabiojunio "mais apresentável"?

5. Vocês acham que essa venda irá se concretizar? 


\section{Trecho 7}

- Vê se não chora quando eles chegarem, senão eu te mato, viu? E nada de se sujar porque o sabão já está acabando. Tem que ficar limpo até depois de amanhã. Melhor nem se mexer muito, fique quieto dentro de casa.

Fabiojunio olhava os preparativos meio assustado.

1. O que Marialva pede ao filho?

2. Como Fabiojunio está se sentindo?

3. O que podemos saber sobre o comportamento de Fabiojunio por meio das ordens que Marialva dá ao filho?

4. Como vocês pensam que Fabiojunio vai agir a partir de agora?

\section{Trecho 8}

Mas as fotos dos irmãos cercados de conforto, carinho e comida já o tinham convencido. Tanto Tião quanto Francineide e Ronivon pareciam muito felizes. Assim, quando chegou o casal, despediu-se da mãe e de Simara - a irmã mais velha —, engoliu o choro e entrou no carro de seus novos pais.

1. Quais novos personagens são apresentados e o que ficamos sabendo sobre eles?

2. O que levou Fabiojunio a se convencer a ir?

3. Como ele se sente ao entrar no carro dos novos pais?

4. O que a reação de Fabiojunio nos diz diante do modo como ele enfrenta a situação?

5. Como vocês imaginam que será a vida de Fabiojunio com os novos pais?

\section{Trecho 9}

- Mãe, a senhora não achou esses dois aí meio esquisitos, não? - perguntou a menina assim que o carro sumiu na estrada.

— Bobagem, menina. Rico é tudo esquisito mesmo.

1. O que Simara acha dos novos pais?

2. Como a mãe responde à filha?

3. O que ficamos sabendo sobre os novos pais?

4. Ao responder Simara, Marialva justifica o que a filha sente como sendo proveniente da diferença entre ricos e pobres. De que forma o termo "esquisito" pode ser entendido conforme Marialva?

5. O que vocês acham que esse casal tinha que poderia justificar chamá-los de "esquisitos"? Ou Dinâmica de elaboração de hipóteses

Trecho 10

Mas, no fundo, achou que a filha tinha razão. Não sabia dizer direito o que era - se a expressão meio vazia do casal, o jeito que eles tinham de olhar, meio fixo, sempre para frente, a maneira de se moverem, lenta demais.

1. Confrontar as hipóteses elaboradas com as confirmações do texto. Ou finalizar a dinâmica.

2. Marialva usa como justificativa para a esquisitice a expressão do rosto do casal, o jeito de olhar

e a maneira de se mover. Com base nisso, como podemos dizer que foi o primeiro contato entre Marialva e o casal?

3. "No fundo", Marialva também sente certa estranheza vindo do casal. O que vocês acham que ela fará? 


\section{Trecho 11}

Bobagem, repetiu mentalmente. Eram os mais ricos, os que tinham pago mais caro. Olhou para as notas em cima da mesa. Dava para comprar um monte de sabão e botar Simara para lavar roupa para fora.

O problema era justamente a filha, que não parava de tagarelar. Menina inconveniente. Tinha dez anos, só por isso não dava mais para vendê-la. Ninguém queria criança grande assim. Pois que ficasse quieta e ajudasse a fazer o dinheiro render - porque aquele era o último.

1. Qual característica dos novos pais faz com que Marialva considere o que pensa sobre eles ser apenas "bobagem"?

2. Quais informações novas sobre Simara nós ficamos sabendo?

3. No início da narrativa, Marialva diz querer uma vida melhor para os filhos. Neste momento da narrativa, percebemos a mesma preocupação?

4. Em função disso, quais mudanças percebemos em Marialva?

5. Fabiojunio foi o último a ser vendido e Simara era considerada "velha" para ser vendida. O que vocês imaginam que vai acontecer com Simara?

6. O que vocês acham que pode acontecer quando o dinheiro acabar?

\section{Trecho 12}

Isso era o que Marialva pensava. Menos de um mês depois da partida de Fabiojunio, chegou uma carta.

1. O que de fato aconteceu?

2. Após quanto tempo isso ocorre?

3. Quem vocês pensam ter enviado a carta?

4. O que vocês imaginam que esteja na carta?

Trecho 13

Trazia uma foto do menino e mais dinheiro ainda. A mulher ficou radiante.

- Eles devem estar mesmo muito encantados com Fabinho para mandarem essa dinheirama toda - disse ela arregalando os olhos.

Simara, sempre desconfiada, examinava a fotografia.

- Mãe, olha só...

Mas a mulher arrancou a foto de sua mão.

— Olha só digo eu, Simara! Sempre foi lindinho, o seu irmão. Mas com essas roupas... Benza

Deus! Parece um príncipe.

1. O que Marialva recebe na carta?

2. Como Marialva reage ao ver o dinheiro?

3. Como Simara reage ao recebimento da carta?

4. Qual é o estado de espírito de Marialva ao retrucar o comentário de Simara?

5. Por que Marialva age dessa forma com a filha?

6. Por que vocês acham que esta família enviou mais dinheiro para Marialva?

7. O que vocês pensam que Simara queria falar com a mãe?

8. O que vocês imaginam que chamou a atenção de Simara ao examinar a fotografia?

9. Como vocês imaginam que Fabiojunio está na foto? 
$\mathrm{Na}$ foto, o menino estava de pé, em meio a um imenso jardim sem flores, mas com o gramado muito bem cuidado, ao fundo do qual se via um casarão com a fachada ornamentada. Vestia sapatos pretos de verniz, meias brancas, terninho azul-marinho combinando com a bermuda, camisa branca de colarinho e gravata de cetim cinza-claro. O cabelo estava penteado para trás, cheio de goma.

1. Confrontação das hipóteses sobre a fotografia com o texto.

2. Como é o lugar onde Fábiojunio está?

3. Retornem ao trecho 5 e ao trecho 8 , que narram sobre as fotografias de Tião, Ronivom e Francineide, leia-os e diga como eles estão descritos.

4. Como é o lugar onde está Tião, Ronivom e Francineide?

5. Ao compararmos a descrição da foto de Fabiojunio com a foto de seus irmãos, o que se percebe de diferente nos dois ambientes?

6. Fabiojunio, na fotografia examinada por Simara, realmente "parece um príncipe". O que vocês acham que poderia haver de estranho na fotografia e que possa ter chamado a atenção da irmã?

\section{Trecho 15}

Simara não se convencia. Todos os outros irmãos enviavam fotos em que apareciam cercados de brinquedos, em parques, comendo doces, rindo, abraçados com a nova família. Fabiojunio não. Estava sozinho, de pé, com os braços estendidos ao longo do corpo, no meio daquele jardim imenso. Parecia triste.

1. O que está incomodando Simara?

2. O que é narrado e que permite ao narrador enunciar que Fabiojunio "parecia triste"?

3. De acordo com o que é narrado sobre os demais irmãos já adotados, podemos dizer que eles estão se sentindo de que forma?

4. Tendo em vista que o narrador enuncia que "Simara não se convencia", o que vocês acham que vai acontecer?

\section{Trecho 16}

Simara insistiu no assunto, mas Marialva proibiu a filha de prosseguir.

- Gente chique é assim. Não fica pulando e gritando. Ele está é ficando educado - encerrou a conversa.

No mês seguinte, a mesma coisa. Mais um envelope entregue pelo correio.

1. Como Marialva reage à insistência da filha?

2. Como Marialva justifica o modo como Fabiojunio aparece nas fotos?

3. Quantas cartas Marialva recebeu até agora?

4. Ser educado, na visão de Marialva, é ser de que forma?

5. Com base na periodicidade do recebimento das cartas, já faz quanto tempo que Fabiojunio está longe de Marialva e Simara?

6. O que vocês acham que tem no envelope desta vez? 
Dentro, nem um bilhete. Só mais dinheiro e outra foto.

1. Confrontar hipóteses elaboradas sobre o que teria dentro do envelope.

2. Como vocês imaginam que Fabiojunio está na nova foto?

\section{Trecho 18}

Agora, Fabiojunio aparecia de pé em um quarto amplo e ricamente mobiliado. Estava diante de uma cama alta, de dossel talhado em madeira escura, e ao lado de uma escrivaninha cuidadosamente arrumada. Não havia brinquedos à vista. A roupa não era a mesma da foto anterior, mas muito parecida. $\mathrm{E}$ a expressão do menino também, embora parecesse ainda mais pálido e tristonho.

1. Confrontar hipóteses elaboradas sobre como Fabiojunio está na nova foto.

2. Em que lugar está Fabiojunio nesta fotografia?

3. Vocês conhecem o tipo de mobília desse lugar?

4. Como era o lugar em que agora morava Fabiojunio?

5. Com base na nova foto, que tipo de mudança podemos perceber em Fabiojunio?

6. E Simara, como vocês pensam que ela vai reagir ao ver a nova foto?

7. O que podemos dizer sobre a situação econômica e o comportamento da nova família?

8. De que forma vocês imaginam que está sendo a vida de Fabiojunio?

9. Como vocês acham que Marialva vai lidar com o recebimento de mais dinheiro?

\section{Trecho 19}

- Ele não está feliz - constatou Simara em voz alta, sabendo que a mãe não a ouviria. Estava ocupada demais fazendo planos para o dinheiro que chegara. Já dava até para pensar em comprar um fogão de verdade, com bujão de gás e tudo. E teria comida para fazer todos os dias. $\mathrm{Na}$ verdade, teve muito mais do que isso. Todo mês chegava novo envelope com uma foto e mais dinheiro. Cega pela boa sorte repentina, mal olhava para o filho impresso no papel. la direto para o maço de notas, contava-as avidamente, sorria e fazia mais planos.

Apenas Simara estava cada vez mais intrigada.

1. Confirmar as hipóteses geradas nas perguntas 7 e 10 do trecho 18 sobre Marialva e Simara.

2. O que Simara constata sobre Fabiojunio?

3. Essa mãe, conforme o recebimento das cartas, é a mesma mãe do início da história?

4. Que tipo de hipóteses podemos elaborar para os planos futuros que Marialva fazia sorrindo?

5. Por que vocês acham que Simara estava "cada vez mais" intrigada?

6. Vocês acreditam que continuarão chegando mais cartas?

Trecho 20

A cada foto que chegava, parecia-lhe mais evidente que havia algo muito estranho ocorrendo ao irmão. Sempre o mesmo tipo de roupa, os ambientes luxuosos - mas antiquados e soturnos -, e a expressão ausente, o olhar mortiço, a postura imóvel.

A última foto era ainda mais impressionante.

1. Confirmação das hipóteses geradas na questão 6, do trecho 19.

2.Quais elementos na foto permitem à Simara pensar que "algo muito estranho" estava ocorrendo ao irmão?

3. Ao final, o narrador diz "a última foto era ainda mais impressionante". O que vocês acham que Simara viu nessa foto, a ponto de permitir ao narrador dizer isso?

Ou Dinâmica de escrita em grupo (vide orientações ao professor). 
Solitário, sentado à cabeceira de uma mesa imensa, de madeira escura e polida, Fabiojunio não olhava para a baixela de prata à sua frente, nem para a louça filetada de ouro, nem para os talheres de cabo de madrepérola. Seu olhar tampouco se dirigia para o fotógrafo. Parecia fixar-se num ponto impossível, distante, muito além da realidade.

1. Concluir a dinâmica em grupos (vide orientações ao professor).

2. O que vocês acham que está acontecendo com Fabiojunio?

3. Como vocês acham que Simara vai reagir agora?

4. Dinâmica performática. (vide orientações ao professor)

\section{Trecho 22}

Intrigada com aquilo, Simara foi até a casa do padre e pediu-lhe emprestada sua lente de aumento. Já tinha visto o objeto algumas vezes depois das aulas de catecismo. Parecia mágico, com seu poder de ampliar pequenos detalhes. Quando era menor, adorava pegar a lente e observar a ponta de seu polegar, descobrindo as finas linhas que desenhavam redemoinhos em seus dedos.

Mas, agora, não havia tempo para brincar. Botou a foto sob o vidro da lente e examinou-a detidamente. Nem precisou procurar muito. Bastou-lhe focalizar os olhos do irmão para encontrar a explicação de sua expressão vazia:

1. Novamente, o padre que tentou "demover" Marialva retorna à narrativa, pois é a ele que Simara recorre. Qual o motivo de Simara pedir uma lupa emprestada ao padre?

2. Para que Simara encontre a explicação para a expressão vazia de Fabiojunio, ela precisou de uma lupa. O que isso pode nos dizer sobre a perspectiva da fotografia?

3. Quais hipóteses podemos levantar sobre o que Simara viu nos olhos do irmão, na foto, que permitiram a ela entender a sua expressão vazia?

Ou Dinâmica de escrita (vide orientações ao professor)

Trecho 23

estavam furados. No lugar das córneas, havia apenas dois buracos negros, redondos e perfeitos. Com um grito apavorado, Simara chamou o padre.

1. Quais hipóteses puderam ser confirmadas da questão 3, do trecho 22 ?

$\mathrm{Ou}$

Conclusão da dinâmica (vide orientações)

2. O que vocês acham que pode ter acontecido a Fabiojunio para ele estar com os olhos furados?

3. Como vocês acham que o padre vai reagir ao saber o que Simara constatou? 
Trecho 24

O homem fez o sinal-da-cruz e prontificou-se a acompanhar a menina até a residência do casal que tinha levado Fabiojunio embora.

1. E então, o que padre André resolve fazer para ajudar Simara?

2. Vemos que o padre se propõe a acompanhar Simara até a casa em que está Fabiojunio. O que vocês acham que ele irá levar para enfrentar a situação?

Trecho 25

Foi só o tempo de pegar uma pesada cruz de prata, um vidro de água benta e o dinheiro da passagem de ônibus. Com o envelope nas mãos, a menina o seguiu até a rodoviária.

Alta Cruz ficava a apenas sessenta quilômetros de distância. Duas horas de viagem na condução velha e malcuidada. Simara sacolejava pela estrada, impaciente. O padre, no entanto, ignorava a ansiedade da menina e traçava cuidadosamente seu roteiro. Iriam primeiro à igreja local buscar informações sobre a família. Se possível, levariam o pároco junto com eles até a casa. As fotos diziam claramente que se tratava de um caso de bruxaria e não queria enfrentar uma novidade daquelas sozinho.

Chamava-se padre André, era jovem e destemido. Mas também inexperiente e humilde o suficiente para admitir que não tinha a menor ideia do que fazer quando encontrasse o estranho casal.

Não custaram a encontrar a igreja nem a conseguir falar com o padre Leal, um velhinho simpático, que cuidava da paróquia havia mais de trinta anos.

- Estamos com sorte - confidenciou o padre André a Simara. - Há tanto tempo aqui, ele deve conhecer a família.

O padre Leal, no entanto, ficou perplexo ao ver o endereço que Simara Ihe mostrava.

1. Quais objetos padre André leva consigo?

2. Qual ideia ele tem para resolver o caso?

3. Ele está preparado para lidar com isso?

4. Ao escolher uma cruz de prata e um vidro de água benta, podemos dizer que padre André está com medo de que tipo de coisas?

5. Quais podem ser, para vocês, os motivos da perplexidade de padre Leal após ver o endereço?

Trecho 26

- Deve haver algum engano, meus filhos. Esse endereço não existe.

Com um pressentimento ruim, Simara insistiu:

- É muito importante, padre. Por favor, nos ajude a encontrar essa família.

- Mas estou lhe dizendo, filha. Conheço o lugar, não existe casa nenhuma nesse endereço. Essa rua não passa de uma velha estrada abandonada. Nem carroça passa mais por lá.

1. Checagem das hipóteses sobre a perplexidade do padre.

2. Como é o lugar onde deveria estar a casa?

3. Com base nas informações que temos sobre o lugar, que tipo de dificuldades eles podem encontrar para chegar até lá?

4. Se padre Leal estiver certo, de onde vocês imaginam que poderiam estar vindo as cartas?

5. O que vocês acham que Simara e padre André farão diante da afirmativa do padre Leal de que não existe casa naquele endereço? 
Até então, o padre André só observava a conversa. Mas decidiu intervir:

- Padre Leal, temos motivos muito sérios para procurar essa casa - disse, enquanto abria o envelope e espalhava as fotos sobre a mesa.

- Veja isso.

O velho pároco examinou as fotos com as mãos trêmulas enquanto ouvia o relato da história feito por Simara. Por fim, deteve-se na que mostrava Fabiojunio no jardim. Após observá-la por alguns instantes, mergulhou a cabeça nas mãos, murmurando:

- Não consigo acreditar...

1. Como padre Leal fica ao ver as fotos?

2. Qual é a foto que mais chama a atenção dele?

3. Baseado no que já lemos até o momento, como vocês explicam os "motivos muito sérios" dos quais fala padre André?

4. Considerando o estado "apavorado" de Simara ao mostrar a foto ao padre, o que podemos inferir sobre o modo como é relatado a história ao padre Leal?

Ou Dinâmica performática (vide orientações)

5. Quando padre Leal diz: "Não consigo acreditar...", o narrador usa reticências, de forma a sugerir que há mais coisas em jogo para além das que estão sendo ditas. O que poderia ser o que não está escrito nas reticências?

\section{Trecho 28}

Simara não se conteve e perguntou:

- O senhor conhece essa casa?

O religioso deu um profundo suspiro. Estava pálido e limitou-se a acenar afirmativamente com a cabeça. Mal conseguia falar.

Mas a menina era determinada. E não queria perder mais tempo.

— Então, nos leve até lá. Acho que meu irmão está correndo perigo.

1. Com quais termos e/ou expressões, o narrador sugere que Simara está impaciente?

2. Qual termo e/ou expressão o narrador usa para demonstrar que Simara não estava com medo do que ela poderia enfrentar para ajudar ao irmão?

3. Tendo em vista que, diante dos fatos, padre Leal fica pálido e suspira, o que podemos dizer sobre seu estado emocional?

4. Vocês acham que padre Leal vai atender ao pedido de Simara?

5. Quais poderiam ser os perigos que Fabiojunio estaria correndo?

Trecho 29

O religioso limitou-se a balbuciar:

- Seu irmão está morto.

1. Sabemos, por meio do narrador, que padre Leal está "há mais de trinta anos" cuidando da paróquia; além disso, ele mesmo diz afirmativamente: "Conheço o lugar". Com base nisso, o que podemos dizer sobre os conhecimentos prévios do padre que o leva a dizer: "não consigo acreditar" e afirmar "seu irmão está morto"?

2. Com base no que inferimos na pergunta anterior, o que vocês acham que padre Leal sabe?

3. Como vocês acham que Simara e padre André vão reagir à fala de padre Leal? 
Padre André não se deu por vencido.

- Precisamos da sua ajuda. Talvez ainda possamos salvá-lo. Tenho certeza de que se trata de um caso de bruxaria.

O velho o interrompeu:

- Vou levá-los até o local.

Assim que entraram no velho Dodge Dart do pároco, este olhou para o padre André e disse:

- Preparem-se para ver uma coisa terrível.

1. Confirmação das hipóteses sobre as reações de Simara e padre André.

2. Considerando que padre Leal diz que o irmão de Simara está morto e que padre André diz que talvez ele ainda possa ser salvo, quais as diferenças de perspectivas entre os dois padres, no que diz respeito ao acontecimento, podem ser percebidas?

3. Que hipóteses vocês podem formular sobre o que seria essa "coisa terrível"?

Ou Dinâmica de elaboração de hipóteses (vide orientações)

\section{Trecho 31}

Com o rosto amargurado, o religioso deu a partida no carro e recusou-se a responder a qualquer pergunta durante o trajeto. Cerca de vinte minutos depois, saiu da estrada principal e tomou um caminho abandonado e coberto de mato pelo qual o veículo avançava com dificuldade crescente. Quanto mais andavam, mais ermo tornava-se o local. Estava claro que havia muito tempo que ninguém passava por ali.

Finalmente, pararam num ponto a partir do qual seria impossível prosseguir com o carro. O mato era tão alto que batia no peito dos dois homens e cobria a cabeça de Simara. Saltaram, e o religioso suspirou:

- A partir daqui, teremos que seguir a pé.

Nem Simara nem padre André ousaram abrir a boca. Apesar do sol quente da tarde, a luminosidade do lugar tinha um toque pouco natural. E um silêncio sepulcral envolvia o caminho, como se ali não houvesse vida: nem insetos, nem animais, nem mesmo vento.

Depois de uns dez minutos de caminhada, uma clareira abriu-se abruptamente. À frente do grupo, surgiu um imenso terreno abandonado. Nem mesmo mato crescia ali, como se a terra tivesse sido amaldiçoada.

Ao olhar para a cena, Simara deu um grito.

1. Conclusão da dinâmica de elaboração de hipóteses.

2. Quais são as evidências, no texto, de que o lugar estava abandonado há bastante tempo?

3. Para justificar o "toque pouco natural" do lugar, o narrador faz duas comparações. Quais são elas?

3. Percebemos que padre Leal, sem problemas para encontrar o lugar, percorre uma "estrada principal", depois toma "um caminho abandonado", para depois, "seguir a pé". O que isso nos diz sobre o conhecimento que o padre tem sobre esse lugar?

4. O que vocês imaginam que seja a cena que Simara viu e fez com que ela desse um grito? 
Reconheceu, ao longe, o casarão ornamentado. No entanto, à sua frente, erguia-se uma ruína, abandonada havia muitos anos em meio ao terreno desolado.

Não havia dúvida nenhuma, era a casa da foto. Ou era a casa como teria sido muitas décadas atrás.

1. Confirmação das hipóteses elaboradas na questão 4, do trecho 31.

2. De que lugar Simara "reconhece" o casarão ornamentado?

3.O que o narrador sugere ao usar a construção verbal "teria sido"?

4. Quais elaborações podemos fazer para o fato de a mesma casa que aparece nas fotografias estar, agora, em ruínas?

5. Ao se deparar com esse cenário, quais podem ser as possíveis reações de Simara?

\section{Trecho 33}

- Vamos até lá - disse Simara energicamente. Ainda não conseguia acreditar no que via.

Partiu na frente, seguida pelos dois religiosos, ambos empunhando suas cruzes.

Não tinha medo. Não sentia nada além de uma urgência imensa e de uma esperança meio improvável de ainda encontrar o irmão. Abriu o pesado portão com um safanão e foi entrando. Deparou-se com o saguão de entrada, o mesmo que já tinha visto nas fotos. No entanto, agora, as paredes estavam descascadas, as vidraças das janelas, quebradas, a bela escadaria de madeira que conduzia ao segundo andar, destruída. E não existia mais nenhum dos móveis luxuosos que serviam de cenário para as poses de Fabiojunio.

1. Averiguação das hipóteses geradas na questão 5 , do trecho 32.

2. Quais são os termos usados pelo narrador para falar sobre o modo como Simara estava se sentindo?

3. Neste trecho, que ação é feita por Simara que evidencia sua força?

4. Quais termos o narrador usa para marcar que o cenário estava em ruínas?

5. Simara é "determinada" e vai na frente de todos, até mesmo dos padres, que vêm atrás dela com suas cruzes. Com base nisso, o que podemos dizer sobre o modo como os padres estão se sentindo?

6. O cenário, como está descrito, é um lugar totalmente abandonado. Dessa forma, onde vocês pensam que Fabiojunio possa estar?

\section{Trecho 34}

Viu, logo à esquerda, o que deveria ter sido a sala de jantar. A mesa, a mesma onde o irmão aparecera na última foto, ainda estava lá. Comida por cupins, não passava de um monte de madeira podre, coberta por uma espessa camada de poeira e fungos.

Cada vez mais transtornada, percorreu todos os cômodos do térreo até sair no pátio dos fundos, de onde podia se ver um antigo cemitério familiar e nove tumbas.

1. Que móvel Simara reconhece das fotos do irmão e como ele está agora?

2. Que termo o narrador usa para retratar o estado emocional de Simara neste momento?

3. Após percorrer todos os cômodos do térreo, onde Simara chega e com o que ela se depara?

4. Por se tratar de um "cemitério familiar", o que podemos saber sobre as pessoas ali enterradas?

5. Quem vocês acham que possam ser as nove pessoas que estão enterradas nas tumbas?

6. O que vocês acham que Simara irá fazer agora? 
Correu para lá.

Não teve dificuldade em reconhecer o estranho casal que levara seu irmão nas fotografias amareladas que decoravam as duas primeiras sepulturas. Ali, estava a data da morte deles, ocorrida cerca de cinquenta anos antes.

1. Confirmação das hipóteses geradas na questão 6, do trecho 34 .

2. Há quanto tempo eles estavam lá?

3. Quem vocês acham que possam ser as outras sete pessoas sepultadas ali?

\section{Trecho 36}

Próximos das tumbas principais - as mais ricas e enfeitadas - havia sete pequenos jazigos. $O$ último era evidentemente recente e foi para ali que Simara correu. Sobre o túmulo, um nome: Fabiojunio, a última foto que tinha sido enviada à família e a data: apenas uma semana atrás.

1. Confirmação das hipóteses da questão 3 , do trecho 35.

2.. Quais as hipóteses que podem ser elaboradas para explicar o fato de Fabiojunio estar enterrado e estar nas fotos?

3. O que vocês acham que Simara irá fazer a partir de agora?

\section{Trecho 37}

Não tinha mais nada para ser visto ali. Tudo o que Simara queria era voltar para casa e contar para a mãe o que tinha descoberto. Deu meia-volta e saiu enxugando as lágrimas enquanto andava cada vez mais rápido, seguida pelos dois religiosos que ainda empunhavam suas cruzes, sem saber muito bem o que fazer com elas.

A viagem de volta foi lenta e silenciosa. O ônibus quebrou duas vezes e Simara só chegou em casa no dia seguinte.

1. Confirmação das hipóteses elaboradas na questão 3, do trecho 36.

2. Como foi a viagem de volta para casa?

3. Qual vocês acham que será a reação de Marialva quando Simara chegar em casa depois de passar uma noite fora?

\section{Trecho 38}

Achava que encontraria a mãe preocupada, mas a velha senhora estava radiante quando abriu a porta para a filha.

1. Confirmação das hipóteses geradas na questão 3 , do trecho 37.

2. Simara pensava que acharia a mãe preocupada. Por que ela achava isso?

3. Quais motivos vocês acham que fizeram Marialva ficar "radiante"? 
— Por que você não disse que ia visitar seu irmão? - perguntou a mulher com um sorriso.

Antes que a menina pudesse responder, a mãe mostrou-lhe um novo envelope.

- Olha só, acabou de chegar! Veio com uma carta. E com ótimas notícias.

Simara avançou para o envelope. A primeira coisa que viu foi a foto.

1. Confirmação das hipóteses sobre a questão 3 , do trecho 38.

2. De que forma Marialva fica sabendo que Simara foi visitar o irmão?

3. Com base em outros momentos da narrativa em que Marialva fica feliz, o que pode indicar as "ótimas notícias"?

4. De quem vocês imaginam ser a foto que acabou de chegar?

\section{Trecho 40}

Uma foto dela, vestida com roupas elegantes e antiquadas, de pé, braços estendidos ao longo do corpo, no pátio dos fundos da casa, onde havia o cemitério, embora a foto não mostrasse cemitério algum. Só um bonito jardim, com o gramado muito bem cuidado e árvores frondosas ao fundo.

Antes que pudesse se recuperar do susto, a mãe perguntou:

- Leu a carta?

1. Confirmação das hipóteses da questão 4, do trecho 39.

2. Quais hipóteses podem ser elaboradas sobre o conteúdo da carta?

\section{Trecho 41}

Eles ficaram encantados com você!

E completou, sorridente:

— E vêm buscá-la hoje mesmo, à noitinha. Você nem imagina como me pagaram bem!

Diante do olhar apavorado da menina, Marialva franziu o cenho e engrossou a voz:

- Já para o banho. Está na hora de você também aprender a ser chique.

1. Confirmação das hipóteses elaboradas na questão 2, do trecho 40.

2. A foto de Fabiojunio no túmulo data de uma semana atrás. Isso coincide com qual acontecimento na narrativa?

3. Como vocês entendem o fato de Simara, enquanto estava no cemitério familiar, aparecer também em uma foto sob o fundo de um belo jardim?

Sugestão ao professor:

Para a leitura do final do conto, a partir do trecho 38, apontamos duas sugestões ao professor. Uma delas em que se dê continuidade à leitura dos trechos finais, estruturando as questões nos eixos trabalhados; outra sugestão é que seja feita uma dinâmica em que os alunos receberão os trechos finais, em um único texto, em forma de carta. Esta dinâmica está detalhada nas orientações ao professor. 


\section{Dinâmica de elaboração de hipóteses - $O$ que é esquisito para você?}

Esta dinâmica tem como foco o aspecto de elaboração de hipóteses na passagem de um trecho para o outro, no processo de leitura proposto. Essas hipóteses formuladas pelo leitor implicam suas projeções de leitura, que vão sendo confirmadas ou refutadas, no decorrer do processo interativo com o texto. Assim, parece-nos interessante promover uma prática, que permita explicitar para os alunos aspectos, que envolvem essas projeções.

Esta dinâmica de leitura proposta consiste na criação coletiva de um quadro de hipóteses, a partir da leitura do trecho 9 , sobre os elementos que possam permitir dizer que a família era esquisita. Assim, feita a leitura do trecho, o professor deve mediar as questões de mapeamento e inferências e, após isso, iniciar a construção do quadro de hipóteses. O docente pode usar a própria lousa para executar essa ação, projetando uma divisão do quadro em três partes.

A primeira etapa envolve a criação de hipóteses com pouca mediação do professor. Sugerimos que os trabalhos com esses trechos sejam feitos em sequência, seja na mesma aula, seja em aulas geminadas, de modo que o processo não seja interrompido.

Sugerimos que o docente adote os seguintes procedimentos*:

- Questionar oralmente a turma sobre "quais elementos nos permitiriam dizer que a família era esquisita?";

- Permitir que os alunos falem livremente sobre suas hipóteses;

- Ir topicalizando no quadro as respostas;

- Não censurar nenhuma hipótese feita pelos alunos.

*Tais procedimentos são sugestões para uma forma de execução que pretendemos ao conceber as atividades de leitura. Contudo, em função de cada turma e/ou realidade de trabalho, podem ser necessárias adequações e modificações por parte do professor.

Dessa forma, até o momento, o quadro do professor estará da seguinte forma:

\begin{tabular}{|c|c|}
\hline & (espaço em branco para posterior colocação do título) \\
\hline $\begin{array}{l}\text { Hipóteses } \\
\text { *AAAAAA } \\
\text { *BBBBBB } \\
{ }^{*} \text { CCCCCC } \\
{ }^{*} \text { DDDDDD } \\
\text { *EEEEEEE } \\
\text { *XXXXXX }\end{array}$ & 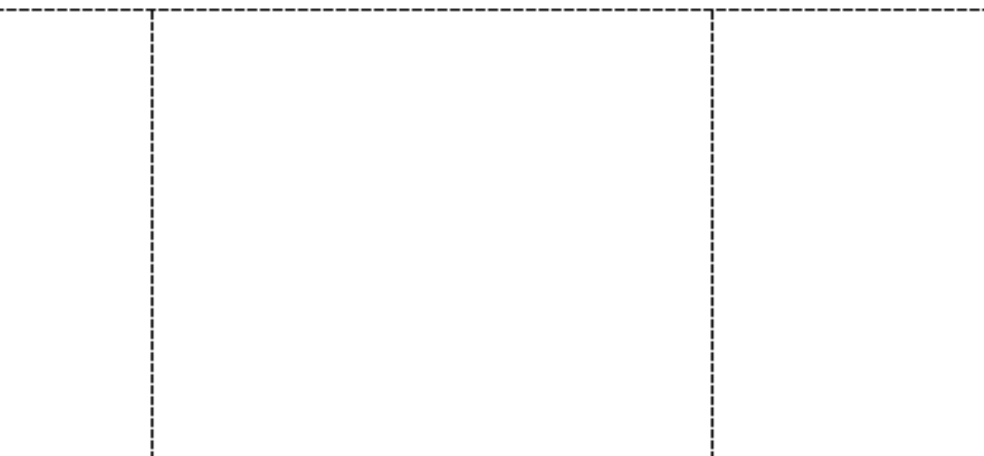 \\
\hline
\end{tabular}

Obs.: As linhas pontilhadas são projeções dos espaços em que o quadro se organiza. 
Na segunda etapa, o professor deve mediar a turma sobre a validade de cada hipótese. Sugerimos ao professor:

- Ler cada hipótese elencada e questionar "é possível elaborar essa hipótese de acordo com o texto?";

- Caso a hipótese não seja validada pela turma, marcá-la para diferenciá-la das outras;

- Repetir o processo de validação com todas as hipóteses.

Neste momento, o professor usará a segunda parte da lousa para elencar as novas hipóteses, que tenham sido validadas como plausíveis pela turma em relação ao texto. Sugerimos ao professor:

- Questionar aos alunos sobre que tipo de "esquisito" nós costumamos lidar e que poderia ter relação com o texto;

- Deixar que eles discutam livremente por um momento;

- Ir elencando, ao lado das primeiras hipóteses, as hipóteses legitimadas pela turma;

- Diferenciar os dois tipos de hipótese com os subtítulos: 1. Hipóteses gerais e 2. Hipóteses plausíveis.

Dessa forma, o quadro do professor ficará do seguinte modo:

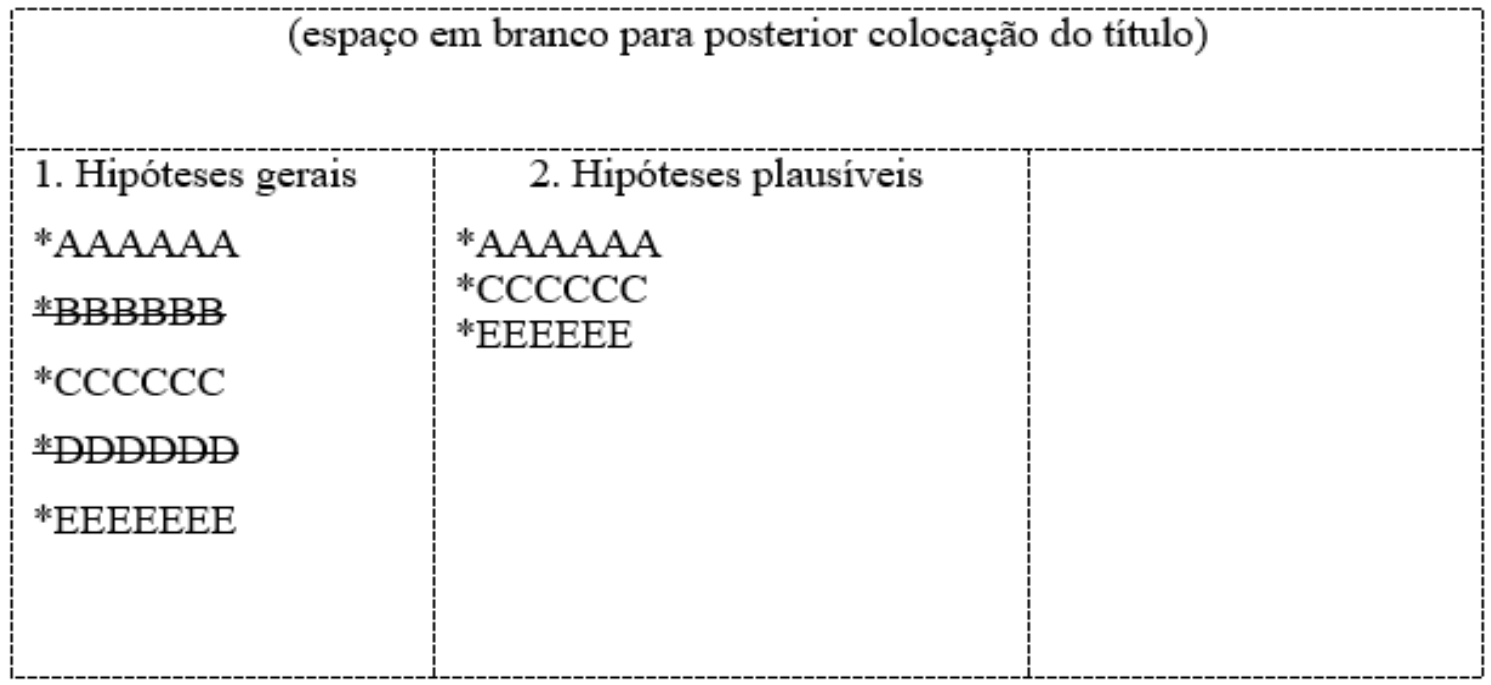

A terceira etapa será o momento da aferição das hipóteses, por meio da leitura do trecho 10. Sugerimos ao professor:

- Fazer a leitura em voz alta do trecho 10;

- Questionar aos alunos o que, de fato, com os dados do texto até o momento, torna essa família esquisita;

- Fazer o mapeamento dos elementos que tornam a família esquisita;

- Elencar, no último espaço do quadro, as respostas da turma;

- Diferenciar essa coluna com o subtítulo "checagem das hipóteses";

- Comparar as hipóteses, para verificar quais delas mais se aproximaram do texto. 
Feito isso, o quadro deverá estar do seguinte modo:

(espaço em branco para posterior colocação do título)

1. Hipóteses gerais

*AAAAAA

*BВBВBB

* $\mathrm{CCCCCC}$

*DDDDDP

*EEEEEEE
2. Hipóteses plausíveis

*AAAAAA

*CCCCCC

*EEEEEE
3. Checagem das hipóteses

*Expressão vazia

* Jeito de olhar fixo

*Modo lento de andar

Para concluir a dinâmica, o professor deve explicitar o processo que foi desenvolvido, resgatando o que foi feito em cada um dos três momentos. Sugerimos ao professor:

- Recapitular que as primeiras hipóteses foram elaboradas livremente;

- Relembrar que as hipóteses devem ser sempre confrontadas com o texto;

- Rememorar que a checagem é feita em forma de mapeamento;

- Delimitar as colunas com traços, de forma a concluir o desenho da leitura;

- Dar um título ao quadro.

Espera-se que, ao final, tenhamos o seguinte quadro de elaboração de hipóteses:

\begin{tabular}{|l|l|l|}
\hline \multicolumn{3}{|c|}{ Processo de elaboração de hipóteses } \\
\hline 1. Hipóteses gerais & 2. Hipóteses plausíveis & 3. Checagem das hipóteses \\
*AAAAAA & *AAAAAA & *Expressão vazia $\sqrt{ }$ \\
*BBBBBB & *CCCCCC & *Jeito de olhar fixo $\sqrt{ }$ \\
*CCCCCC & *EEEEEE & *Modo lento de andar $\sqrt{ }$ \\
*DDDDDB & & \\
*EEEEEEE & & \\
& & \\
& & \\
\hline
\end{tabular}

Sugerimos deixar a demarcação das colunas para o final, assim como a colocação do título, por acreditamos que, se o professor desenha o quadro e coloca os títulos de antemão, o processo de construção de hipótese fica sugestionado, impedindo a prática de co-construção de conhecimento por parte dos alunos neste processo. O professor deve ter em mente o modus operandi que organiza toda a dinâmica, mas o aluno só deve contemplar a concepção final do quadro ao participar da dinâmica. A mediação é fundamental, neste sentido, para que o aluno consiga perceber qual percurso deve ser feito na leitura, para que se obtenha o resultado do quadro e 0 conhecimento que ele implica. 


\section{Dinâmica de escrita - Uma foto ainda mais impressionante}

Essa é uma dinâmica que se vincula ao aspecto da experienciação da escrita literária, enquanto uma das ações necessárias para a efetiva promoção do letramento literário*. Neste sentido, concebemos estratégias de mediação, de caráter coletivo, para que o aluno possa experimentar, por meio da linguagem literária, alguns aspectos da construção narrativa. Para esta dinâmica, que se estrutura em três etapas, a ideia é trabalhar a estratégia de leitura da categoria de pergunta de elaboração de hipótese por meio de uma prática de escrita.

No trecho 20, o foco com a questão de elaboração de hipótese recai na figura do narrador. O professor pode tanto manter a estratégia desenvolvida até o momento, na estrutura de perguntas e respostas orais (para tal, elaboramos a questão 34 ) ou trabalhar na perspectiva proposta pela dinâmica em questão.

Para a aplicação da dinâmica, sugerimos ao professor que adote as seguintes ações iniciais:

- Dividir a turma em grupos de cinco/seis alunos;

- Fazer a leitura do trecho 20, enfatizando o final "A última foto era ainda mais impressionante";

- Propor aos alunos a questão: O que vocês pensam que possa ser tão impressionante nesta foto?;

- Deixar que os alunos discutam a questão livremente, por alguns momentos, enquanto acompanha cada grupo.

Como forma de organizar a escrita do texto, a sequência da dinâmica consiste na escrita dos principais tópicos gerados na discussão. É o momento entre a formulação das ideias e o desenvolvimento de uma delas. Também é importante, neste momento, uma nova rodada de discussão, para que seja ponderada a plausibilidade das hipóteses. É um momento fundamental para o professor conseguir avaliar se e quanto da prática de releitura os alunos já se apropriaram até o momento. Sugerimos ao professor que adote as seguintes ações:

- Pedir aos alunos que, ainda em grupos, registrem, de forma topicalizada, em folha separada, as hipóteses que foram levantadas durante a discussão;

- Propor aos grupos uma discussão entre eles, para que avaliem se as hipóteses são plausíveis ou não.

* Para mais esclarecimentos sobre as ações necessárias para a prática do letramento literário, vide a subseção "letramento literário em sala de aula", na seção "pressupostos teóricos", que se encontra no material dissertativo que acompanha este Caderno Pedagógico. 
A terceira etapa da dinâmica consiste na escrita da descrição da última foto de Fabiojunio. Entendemos que, após a discussão em grupo, a organização dos tópicos das hipóteses e a avaliação coletiva da turma, o aluno tenha subsídios para desenvolver a ação de escrita de forma satisfatória. Sugerimos ao professor:

- Explicar aos alunos que, a partir da discussão e do material que produziram até o momento, eles irão fazer a descrição da foto;

- Explicar sobre a necessidade de se manter certo paralelismo com as descrições das fotos anteriores, lembrando aos alunos que os momentos de narração das fotos recebidas trazem primeiro a descrição do lugar;

- Explicar sobre a coerência, para que se alcance o sentido de "mais impressionante" no contexto da narrativa, lembrando aos alunos que, nas fotos recebidas até então, Fabiojunio, gradualmente, parece, aos olhos de Simara, "triste", "cada vez mais triste";

- Entregar a seguinte ficha de escrita aos grupos e questionar: como vocês fariam a descrição desta nova foto?

\section{Ficha de escrita coletiva}

Questão: Desde a primeira foto de Fabiojunio, o narrador destaca a inquietação de Simara. A cada nova foto que chegava, observamos gradualmente a estranheza da irmã em relação ao modo como Fabiojunio se apresenta, o que a leva a concluir que "ele não está feliz". Chegamos ao ponto em que o narrador diz que "A última foto era ainda mais impressionante".

Grupo:

\section{Descrição da foto:}

Acompanhar cada grupo para orientações pontuais durante a escrita.

Após a escrita pelos grupos, o professor deve recolher as produções e, se possível, digitá-las para a posterior leitura da turma. Feito isso, sugerimos ao professor:

- Fazer a leitura dos textos produzidos;

- Sugerir que a turma avalie a coerência de cada produção dentro do contexto do conto lido até o momento de forma oral e compartilhada. 
O desfecho da dinâmica é feito com a leitura do trecho 21 , para que se possa estabelecer a confrontação das produções dos alunos com o texto. Neste momento, o professor deve mediar o processo como forma de checagem de hipóteses. Sugerimos ao professor:

- Fazer a leitura do trecho 21;

- Mapear a descrição de Fabiojunio, conforme a última foto;

- Realizar, juntamente com a turma, uma comparação entre as suas produções e o trecho no conto, de modo a ponderar não sobre aproximações e distanciamentos das escolhas do autor para a descrição, mas sim sobre plausibilidade e coerência dentro do contexto narrado até o momento, assim como sobre coerência discursiva do narrador. 


\section{Dinâmica performática - 0 olhar além da realidade}

A proposta desta dinâmica tem como objetivo uma prática de escrita e uma de encenação do trecho 21 da narrativa. Entendemos que essa pode ser uma forma interessante de dinamizar a leitura, para que os alunos possam experimentá-la por meio da visualização da cena. Entender a configuração dessa cena é fundamental para a leitura da narrativa, pois é após este momento que a aproximação do aspecto fantástico se apresenta. O trecho 21 , de forma comparativa ao curta do instrumento diagnóstico, assemelha-se ao momento em que o pai vê o outro garoto embaixo da cama. Reforçar, então, este momento de engendramento do que permitirá a aproximação do fantástico é uma forma de tentar ancorar os sentidos do texto, evitando que os alunos rompam os mapeamentos e inferências realizados até o momento, tal como fizeram na leitura do curta, mantendo o jogo de elaboração de hipóteses na ordem do plausível com a estrutura do texto lido.

Esta dinâmica estrutura-se em quatro etapas. A primeira consiste em mapear as transformações de Fabiojunio e a relação com o ambiente em que vive. Esse mapeamento será realizado através da construção de um quadro coletivo em que serão elencados cinco momentos na trajetória do personagem até o momento em questão da narrativa. A segunda etapa consiste em construir um quadro comparativo sobre cada família, também de forma coletiva. A terceira consiste em preparar a escrita para a performance e deve ser feita em grupos. A quarta etapa consiste em executar a performance propriamente dita.

Sugerimos, na primeira etapa, que o professor faça a retomada de cinco momentos da vida de Fabiojunio, tendo como projeto o seguinte esquema:

\begin{tabular}{|l|l|l|l|}
\hline Momento 1 & Momento 2 & Momento 3 & Momento 4 \\
\hline
\end{tabular}

O professor deverá questionar aos alunos e elencar os aspectos da vida de Fabiojunio:

- No momento um (trecho 6);

- No momento dois (trecho 7);

- No momento três (trechos 14 e 15);

- No momento quatro (trecho 18);

- No momento cinco (trecho 20);

De forma que, ao final, tenhamos o seguinte quadro:

\begin{tabular}{|c|c|c|c|c|}
\hline $\begin{array}{l}\text { Momento 1 } \\
\text { *Brinca; } \\
\text { *Não fica em } \\
\text { casa; } \\
\text { *Se suja. }\end{array}$ & $\begin{array}{l}\text { Momento } 2 \\
\text { *Toma banho; } \\
\text { *Fica em casa; } \\
\text { *Está com medo. }\end{array}$ & $\begin{array}{l}\text { Momento } 3 \\
\text { * Sozinho; } \\
\text { *Em pé no jardim; } \\
\text { *Parece triste. }\end{array}$ & $\begin{array}{l}\text { Momento } 4 \\
\text { *Sem brinquedos; } \\
\text { *Ainda mais } \\
\text { pálido e tristonho. }\end{array}$ & $\begin{array}{l}\text { Momento 5 } \\
\text { *Olhar mortiço; } \\
\text { *Expressão } \\
\text { ausente; } \\
\text { *Postura imóvel. } \\
\text { *Olhar fixo em } \\
\text { um ponto "além } \\
\text { da realidade" }\end{array}$ \\
\hline
\end{tabular}


Após elencar no quadro os aspectos de Fabiojunio nos cinco momentos em questão ao longo da narrativa, o professor deve relacionar as mudanças do garoto com os lugares onde vive. Sugerimos que o professor questione:

* Em que ambiente Fabiojunio está em cada um dos momentos?

Neste sentido, esperamos que os alunos percebam que, nos Momentos 1 e 2, Fabiojunio está em sua casa de origem e que, nos outros momentos, está na nova casa. Assim, o quadro ficará do seguinte modo:

\begin{tabular}{|c|c|c|c|c|}
\hline $\begin{array}{l}\text { Momento } 1 \\
\text { *Brinca; } \\
\text { *Não fica em } \\
\text { casa; } \\
\text { *Se suja. }\end{array}$ & $\begin{array}{l}\text { Momento } 2 \\
\text { *Toma banho; } \\
\text { *Fica em casa; } \\
\text { *Está com medo. }\end{array}$ & $\begin{array}{l}\text { Momento } 3 \\
\text { * Sozinho; } \\
\text { *Em pé no jardim; } \\
\text { *Parece triste. }\end{array}$ & $\begin{array}{l}\text { Momento } 4 \\
\text { *Sem brinquedos; } \\
\text { *Ainda mais } \\
\text { pálido e tristonho. }\end{array}$ & $\begin{array}{l}\text { Momento } 5 \\
\text { *Olhar mortiço; } \\
\text { *Expressão } \\
\text { ausente; } \\
\text { *Postura imóvel. }\end{array}$ \\
\hline \multicolumn{2}{|c|}{ Casa de origem } & \multicolumn{3}{|c|}{ Casa nova } \\
\hline
\end{tabular}

Ainda na primeira etapa, o professor deve mediar a discussão, de forma que os alunos percebam que Fabiojunio tem uma vida antes de ser adotado e outra vida depois da adoção. Sugerimos, então, que se questione:

Em que momento se iniciam as mudanças de Fabiojunio?;

- De que forma podemos estabelecer um antes e um depois para a vida dele?

A partir dessa mediação, o quadro passará a ter o seguinte desenho:

\begin{tabular}{|c|c|c|c|c|}
\hline $\begin{array}{l}\text { Momento } 1 \\
\text { *Brinca; } \\
\text { *Não fica em } \\
\text { casa; } \\
\text { *Se suja. }\end{array}$ & $\begin{array}{l}\text { Momento } 2 \\
\text { *Toma banho; } \\
\text { *Fica em casa; } \\
\text { *Está com medo. }\end{array}$ & $\begin{array}{l}\text { Momento } 3 \\
\text { * Sozinho; } \\
\text { *Em pé no jardim; } \\
\text { *Parece triste. }\end{array}$ & $\begin{array}{l}\text { Momento } 4 \\
\text { *Sem brinquedos; } \\
\text { *Ainda mais } \\
\text { pálido e tristonho. }\end{array}$ & $\begin{array}{l}\text { Momento } 5 \\
\text { *Olhar mortiço; } \\
\text { *Expressão } \\
\text { ausente; } \\
\text { *Postura imóvel. }\end{array}$ \\
\hline \multicolumn{2}{|c|}{ Casa de origem } & \multicolumn{3}{|c|}{ Casa nova } \\
\hline \multicolumn{2}{|c|}{$\begin{array}{c}\text { Vida } 1 \\
\text { Antes de ser adotado }\end{array}$} & \multicolumn{3}{|c|}{$\begin{array}{l}\text { Vida } 2 \\
\text { Depois de ser adotado }\end{array}$} \\
\hline
\end{tabular}

Como forma de finalizar esta etapa, o professor deve fazer o desenho das demarcações do quadro e a colocação do título "Transformações de Fabiojunio", ficando desta forma:

\section{Transformações de Fabiojunio}

\begin{tabular}{|c|c|c|c|c|}
\hline $\begin{array}{l}\text { Momento 1 } \\
\text { *Brinca; } \\
\text { *Não fica em } \\
\text { casa; } \\
\text { *Se suja. }\end{array}$ & $\begin{array}{l}\text { Momento } 2 \\
\text { *Toma banho; } \\
\text { *Fica em casa; } \\
\text { *Está com medo. }\end{array}$ & $\begin{array}{l}\text { Momento } 3 \\
\text { * Sozinho; } \\
\text { *Em pé no jardim; } \\
\text { *Parece triste. }\end{array}$ & $\begin{array}{l}\text { Momento } 4 \\
\text { *Sem brinquedos; } \\
\text { *Ainda mais } \\
\text { pálido e tristonho. }\end{array}$ & $\begin{array}{l}\text { Momento 5 } \\
\text { *Olhar mortiço; } \\
\text { *Expressão } \\
\text { ausente; } \\
\text { *Postura imóvel. }\end{array}$ \\
\hline \multicolumn{2}{|c|}{ Casa de origem } & \multicolumn{3}{|c|}{ Casa nova } \\
\hline \multicolumn{2}{|c|}{$\begin{array}{c}\text { Vida } 1 \\
\text { Antes de ser adotado }\end{array}$} & \multicolumn{3}{|c|}{$\begin{array}{c}\text { Vida } 2 \\
\text { Depois de ser adotado }\end{array}$} \\
\hline
\end{tabular}


A segunda parte desta dinâmica consiste na construção do quadro familiar de Fabiojunio antes e depois de ser adotado. O professor deve chamar a atenção dos alunos para as características da família de origem e da família adotiva, de forma que eles resgatem os mapeamentos feitos anteriormente. O projeto de desenho para este quadro é a divisão em duas colunas. O quadro deve fazer oposições entre as marcas de cada família, podendo ficar da seguinte forma:

\begin{tabular}{|l|l|}
\hline Família de origem & Família adotiva \\
\hline *Falantes & *Calados \\
*Pobres & *Ricos \\
*Casa simples & *Casa luxuosa \\
*Não é chique & *Não é chique \\
\hline
\end{tabular}

Como feito anteriormente, somente após elencar no quadro as oposições, é que o professor escreve o título e faz as delimitações da tabela, para que ela fique no seguinte modelo:

Quadro de caracterização das famílias

\begin{tabular}{|l|l|}
\hline Família de origem & Família adotiva \\
\hline *Falantes & *Calados \\
*Pobres & *Ricos \\
*Casa simples & *Casa luxuosa \\
*Não é chique & *É chique \\
\hline
\end{tabular}

Para concluir esta etapa da dinâmica, o professor deve mediar a turma, de forma a relacionar as mudanças de Fabiojunio com o modo de ser de cada família, frisando as transformações do garoto, associando-as ao novo ambiente onde ele está vivendo.

A construção dos dois quadros são estratégias eficazes para a retomada da narrativa em todos os aspectos trabalhados, a saber: os mapeamentos, as inferências e as hipóteses, na tentativa de promover a autonomia de leitura dos alunos. 
A terceira etapa da dinâmica consiste na preparação escrita para a performance. Sugerimos ao professor:

- Montar os grupos de trabalho;

- Ler para a turma o final do trecho 21, a saber: "Seu olhar tampouco se dirigia para o fotógrafo. Parecia fixar-se num ponto impossível, distante, muito além da realidade.";

- Propor que os alunos discutam a questão:

* Como vocês acham que é este olhar de Fabiojunio?;

Entregar, após a discussão, a seguinte ficha para que os alunos registrem, de modo topicalizado, suas hipóteses:

\section{Grupo:}

Como vocês acham que é este olhar de Fabiojunio?

$*$

A quarta etapa é a encenação da performance. Sugerimos que, nesta etapa, o professor adote as seguintes ações:

- Explicar, ainda nos mesmos grupos, aos alunos sobre a performance que será feita;

- Explicar que, após escreverem todas as respostas, o grupo deverá discutir e escolher uma delas, aquela que melhor represente um "olhar distante, muito além da realidade", para fazer a performance;

- Propor que todos os membros ensaiem o modo de olhar de Fabiojunio entre eles e que cada grupo eleja aquele que melhor performou;

- Cada membro eleito deve fazer a performance do olhar para a turma.

Obs.: O professor pode desdobrar a dinâmica em uma quinta etapa para confeccionar, caso haja concordância de todos os participantes e sem obrigatoriedade, um mural das pequenas produções dos alunos ao longo do processo de leitura. Neste caso, as ações para esta produção podem ser as seguintes:

- Fazer a fotografia de cada performance;

- Construir um mural com a fotografias impressas. 


\section{Dinâmica de escrita - A expressão vazia}

Esta estratégia de leitura busca ampliar modos de promover a prática de elaboração de hipóteses. É, portanto, uma outra maneira que propomos para dinamizar as projeções hipotéticas da narrativa em substituição à questão 3 , mas, neste caso, por meio da escrita. A pergunta que permite as elaborações envolve as explicações possíveis encontradas por Simara, de forma a justificar a expressão vazia de Fabiojunio. Por meio desta atividade, pretendemos fornecer meios para que os alunos exercitem a prática de criação de projeções coerentes com a narrativa.

A dinâmica divide-se em quatro etapas. A primeira etapa consiste na discussão coletiva sobre as possíveis causas desse olhar. A segunda é a organização, em grupos, de tópicos de escrita para sistematizar as causas da "expressão vazia". A terceira etapa é o momento em que os alunos elegem um dos tópicos para desenvolver a hipótese do grupo. Por fim, há uma etapa de desfecho da dinâmica em que se promove a plausibilidade das hipóteses elaboradas.

Na primeira etapa, os alunos irão discutir sobre as possíveis causas para o olhar de Fabiojunio estar assim. Desse modo, sugerimos ao professor:

- Fazer a divisão da turma em grupos de cinco/seis alunos;

- Fazer a releitura do final do trecho 22, "Nem precisou procurar muito. Bastou-lhe focalizar os olhos do irmão para encontrar a explicação de sua expressão vazia";

- Propor a questão: qual pode ter sido a explicação encontrada por Simara que justificasse a expressão vazia de Fabiojunio?;

- Deixar que os alunos discutam a questão livremente com o grupo por alguns minutos;

\section{Ficha de escrita coletiva}

\begin{tabular}{|l}
\hline Grupo: \\
\hline \begin{tabular}{l} 
Possiveis explicações encontradas: \\
$*$ \\
$*$ \\
$*$ \\
$*$ \\
\hline \\
\hline
\end{tabular} \\
\hline
\end{tabular}


- Solicitar, após a discussão, a escrita em tópicos de todas as possibilidades discutidas;

$\mathrm{Na}$ segunda etapa, após esse momento de organização do texto, os alunos serão solicitados a confeccionar o texto final com a explicação. Sugerimos ao professor:

- Explicar que todo ato de escrita implica em escolhas, o que se deve narrar e o que deve ficar de fora da narrativa;

- Explicar que o grupo irá discutir e escolher uma das possibilidades e desenvolver essa ideia como se fossem os narradores;

- Entregar a ficha de escrita:

Grupo:

Explicação encontrada por Simara de acordo com o grupo:

- Recolher as produções e digitá-las para posterior validação da turma;

- Entregar aos alunos, na aula seguinte, a folha com as hipóteses dos cinco grupos digitadas;

- Fazer a leitura das produções dos alunos e promover o compartilhamento dos textos;

- Validar coletivamente a coerência dos textos.

O desfecho da dinâmica é a comparação entre as hipóteses elaboradas pelos alunos e o texto do autor, que é o trecho 23. Para tal, sugerimos ao professor:

- Fazer a leitura do trecho 23;

- Analisar, junto aos alunos, as escolhas do narrador;

- Realizar coletivamente um momento para discussão, comparando as escolhas do autor na escrita do conto e as dos alunos na escrita de seus textos. Novamente, é importante pontuar que essa comparação deve ser estabelecida com base na coerência dentro do contexto da narrativa, e não em aspectos de quais sejam os mais criativos. 


\section{Dinâmica escrita e performática - A angústia de Simara}

Esta dinâmica, relacionada ao trecho 27, tem como objetivo promover uma prática de escrita e uma encenação vinculada a essa escrita. Com base nas informações que obtivemos do texto até o momento, o aluno irá trabalhar com o modo como Simara relata para o padre Leal todo o ocorrido. Desse modo, os alunos deverão refletir, com base no estado de espírito da garota e de todas as outras informações que têm sobre a narrativa, de que forma esse relato expressa as possíveis emoções dela.

Essa estratégia é uma forma de o professor resgatar todos os elementos mapeados, inferidos e aferidos, até o momento da leitura. Isso é fundamental neste ponto da narrativa, pois é um momento em que o conto passa por uma transição para apresentar a perspectiva fantástica. $\mathrm{E}$, como vimos no instrumento diagnóstico, é a partir da instauração da hesitação do fantástico que os alunos começaram a romper com os protocolos de leitura, tendendo para o maravilhoso puro ou, em menor escala, para o estranho. Neste sentido, esta dinâmica é uma forma de reforçar o mapeamento geral, a fim de que isso sirva de ancoragem para evitar as rupturas dos pactos de leitura.

Esta dinâmica estrutura-se em cinco etapas. A primeira consiste em resgatar coletivamente com a turma momentos da narrativa em que algo parece "fora do normal". A segunda e terceira etapas têm por finalidade organizar o material escrito para apoiar e preparar a performance. A quarta etapa é a execução propriamente dita da performance e, por fim, a quinta etapa é a promoção de um momento de discussão na turma sobre as encenações.

A primeira etapa da dinâmica consiste em fazer uma retomada geral do conto. Para isso, o professor deve fazer a mediação, conforme o roteiro abaixo, pontuando as informações que são importantes de serem relatadas por Simara ao padre Leal. Para iniciar, sugerimos que, coletivamente, o professor use a lousa para resgatar essas informações, questionando aos alunos:

- Qual o primeiro fato narrado?;

- Qual o primeiro estranhamento de Simara?;

- Como esse estranhamento vai se evidenciando?;

- Mais alguém percebe que algo estranho está acontecendo?;

- Em que momento pode-se confirmar que algo está errado?

*Marialva deccidentorme o roteirio, esperamos que as seguintes informaçoes sejam resgatadas:

${ }^{*}$ O casal que compra Fabiojunio parece esquisito pela expressão, jeito de olhar e de andar;

*Diferente dos outros casais, esses continuam enviando dinheiro e fotos de Fabiojunio;

*Nestas fotos, Fabiojunio está em um lugar sem brinquedos e parece triste;

*Somente Simara tem essa atenção, pois a mãe só pensa em fazer o dinheiro render;

*Simara vê que Fabiojunio está com os olhos furados. 
A segunda etapa da dinâmica consiste na organização escrita para a performance. Para tal, sugerimos que o professor adote as seguintes ações:

- Dividir a turma nos mesmos grupos;

- Pedir, tendo como base a retomada geral do conto, que os alunos escrevam como eles fariam o encadeamento dos fatos a serem relatados;

- Recolher as escritas, que devem ser feitas em folha separada, e entregar na próxima aula*.

A terceira etapa consiste na preparação para a performance. Sugerimos ao professor:

- Devolver os textos aos respectivos grupos;

- Propor aos grupos que discutam as seguintes questões:

* Como vocês acham que Simara contou tudo isso que escreveram, de modo que o relato durou apenas o momento em que o padre Leal olhava a foto?

* Qual era o estado de espírito de Simara ao fazer o relato?

- Promover a escolha de um membro para representar Simara;

- Treinar como se dará o relato para o padre Leal, de forma que transpareça o estado de espírito de Simara, respeitando o que foi elencado para ser dito por ela.

Para instaurar a dinâmica, cada grupo apresentará sua performance para a turma.

Sugerimos a seguinte composição:

- Um membro do grupo para ler a fala de padre André:

"- Padre Leal, temos motivos muito sérios para procurar essa casa.";

- Outro membro para representar a fala de Simara:

"- Veja isso." e inicia o relato;

- Outro membro do grupo para ler a fala de padre Leal:

"- Não consigo acreditar...".

* Sugerimos ao professor que recolha sempre as fichas e as devolva em aula seguinte, para evitar que o aluno não esteja com o material, inviabilizando a continuidade da dinâmica.

Após todas as apresentações, sugerimos ao professor propor e mediar uma discussão com a turma, com o objetivo de avaliarem quais performances cumpriram a proposta. Lembrando que a avaliação não é um juízo de valor sobre quem foi melhor ou pior, mas sim refletir e analisar se as produções estão coerentes com os princípios narrativos que eles estão estudando e como essas produções se relacionam com as escolhas do narrador da obra lida. 


\section{Dinâmica de elaboração de hipóteses - preparem-se para uma coisa terrível}

Esta também é uma dinâmica que se estrutura no eixo de elaboração de hipóteses, seguindo a lógica proposta na estratégia de leitura adotada neste projeto. Como um dos objetivos é que os alunos entendam e adquiram autonomia no processo de elaborar hipóteses de leitura e de validarem ou não essas hipóteses com o avanço da leitura, entendemos ser importante avaliar, de tempos em tempos, o grau dessa autonomia recém-adquirida. Esta dinâmica apresenta-se, assim, como uma proposta desse tipo de avaliação.

$\mathrm{Na}$ estratégia de leitura adotada, os momentos de elaboração de hipóteses são realizados coletivamente com o professor fazendo perguntas à turma sobre suas conjecturas em relação a aspectos do desenrolar da narrativa. As hipóteses elaboradas são anotadas na lousa, analisadas enquanto plausíveis ou não, de acordo com o que foi lido até o momento, e validadas ou não, sempre coletivamente, com o próximo trecho lido da narrativa. A repetição desse processo vai confirmando, para o aluno, um aspecto do ato de leitura que qualquer leitor em formação precisa adquirir para, justamente, tornar-se autônomo. Como esse é um dos objetivos centrais da estratégia aqui aplicada, avaliar, ainda que parcialmente, a aquisição dessa autonomia se faz importante no processo de formação leitora ora proposto. É nesse sentido que concebemos esta dinâmica, que também tem como intuito nos permitir avaliar sua funcionalidade, ou seja, avaliar se ela serve ao intuito de avaliar a aquisição de autonomia do aluno no tópico abordado.

Para tal, propomos a adaptação da estrutura coletiva para a estrutura em grupos. Sugerimos ao professor, então, que adote as seguintes ações:

- Montar os grupos de trabalho (sugerimos um número entre 4 e 6 alunos em cada);

- Ler em voz alta para a turma a questão:

* Que hipóteses vocês levantariam sobre o que seria essa coisa terrível?

- Instruir que as hipóteses, diferentemente das anteriores, não são para serem respondidas oralmente para a turma, mas discutidas pelos membros dos grupos;

- Dar um tempo (a ser estipulado pelo professor em função das características de cada turma com a qual esteja trabalhando) para que aconteça a discussão nos grupos;

- Entregar, após as discussões, a seguinte ficha elaborada:

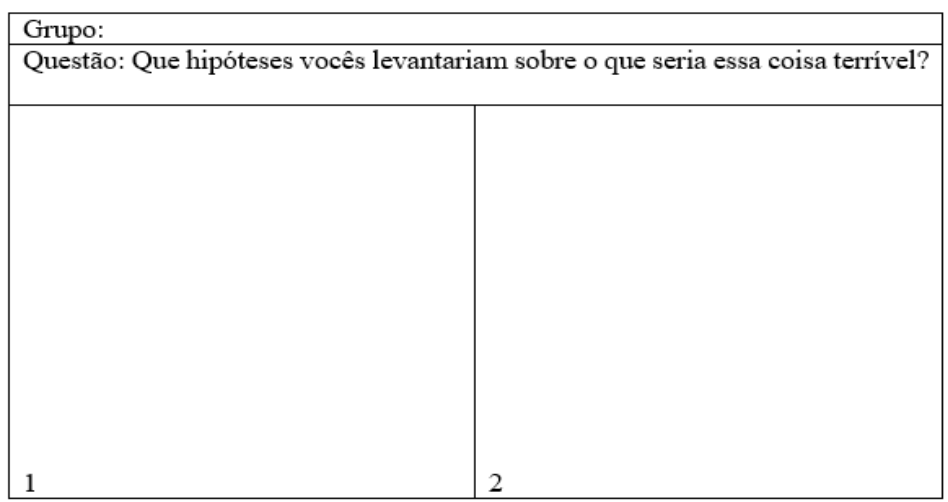


- Explicar que, no primeiro espaço, eles devem escrever todas as hipóteses que foram elaboradas pelo grupo sem tolher nenhuma;

- Dar o tempo para execução da escrita;

- Explicar que eles deverão, agora, analisar cada hipótese, de forma a avaliar se elas são plausíveis em relação ao texto lido até o momento;

- Dar o tempo para a execução da análise;

- Explicar que, no segundo espaço, eles vão escrever as hipóteses que passaram pelo crivo da análise;

- Relembrar com os alunos a diferenciação entre as "hipóteses gerais" e as "hipóteses plausíveis" para colocação dos títulos;

- Recolher as produções para fazer o agrupamento das hipóteses plausíveis;

- Fazer a leitura coletiva das hipóteses selecionadas como plausíveis;

- Promover a avaliação coletiva das hipóteses, questionando se elas estão ou não coerentes e por quê;

O desfecho desta dinâmica consiste em uma discussão comparativa, de caráter coletivo, após a leitura do trecho 31, em que as hipóteses elaboradas pelos alunos são avaliadas em relação às escolhas do narrador. Sugerimos ao professor:

- Fazer a leitura do trecho 31;

- Promover com os alunos a análise das escolhas do narrador;

- Estabelecer, de forma coletiva, o momento de discussão comparativa entre o trecho 31 e as produções dos alunos. 


\section{Dinâmica final - Simara encontra um novo lar}

Pretendemos, com esta dinâmica, avaliar a reação dos alunos à hesitação final que se instaura no conto e de que forma eles lidam com o desfecho da narrativa. Como constatamos no instrumento diagnóstico, os alunos estabeleceram, no curta-metragem, um pacto de leitura fortemente marcado por aspecto do maravilhoso, impedindo a ressignificação das hipóteses, de forma a compactuar a recepção do fantástico. Neste sentido, com a leitura final do conto, pretendemos avaliar se as estratégias que elaboramos na tentativa de ancorar a leitura do texto, de fato, ajudaram a impedir ou minimizar os rompimentos dos pactos de leitura construídos pelos alunos.

Outra avaliação importante de ser feita é sobre a apreciação final dos alunos sobre o conto, ou seja, neste momento, é importante averiguar como ocorre a resposta ao texto lido. A reação observada no curta-metragem foi de uma dificuldade de interação com o aspecto fantástico. Sendo assim, a observação de como será a atitude dos alunos ao final do conto nos permitirá perceber em que sentido a ampliação de repertório literário dos alunos aconteceu.

Para a dinâmica, sugerimos ao professor preparar previamente uma cópia para cada aluno do trecho, que se inicia em "A primeira coisa que viu foi a foto [...]" e termina em "Você nem imagina como me pagaram bem!". Propomos que as cópias sejam colocadas dentro de envelopes, para manter uma proximidade com o universo do conto. A partir disso, sugerimos as seguintes ações a serem executadas na dinâmica:

- Colocar todos os envelopes sobre a mesa do professor ao iniciar a aula;

- Fazer a leitura do seguinte trecho:

"a mãe mostrou-Ihe um novo envelope. - Olha só, acabou de chegar! Veio com uma carta. E com ótimas notícias. Simara avançou para o envelope."

- Pedir que os alunos vão até a mesa, peguem um envelope e voltem para seus lugares;

- Pedir que os alunos abram o envelope e façam a leitura silenciosa do trecho que se encontra nele;

- Fazer uma leitura dramatizada do final do conto, a saber:

"Diante do olhar apavorado da menina, Marialva franziu o cenho e engrossou a voz: - Já para o banho. Está na hora de você também aprender a ser chique." 
Após a leitura, propomos uma discussão. Sugerimos ao professor as seguintes questões a serem feitas:

- $\quad$ O que vocês acharam do conto?;

- $\quad$ O que vocês sentiram ao final da narrativa?;

- Como vocês explicam a fotografia de Simara em um "bonito jardim", ao mesmo tempo em que ela estava em um cemitério?;

- Como vocês explicam as fotos recebidas durante meses, mas a morte de Fabiojunio estar com a data de "uma semana atrás"?;

- Como vocês explicam o fato de um "casarão em ruínas" aparecer nas fotos de modo "ornamentado"?

A finalidade desta discussão é a de evidenciar o aspecto fantástico no desfecho do conto para, a partir disso, o professor poder iniciar a etapa de sistematização. 


\section{Etapa 4: - Sistematização do gênero fantástico}

Objetivo: Apresentar aos alunos o conceito de fantástico na literatura, como proposto por Todorov (2008), de forma comparativa com o maravilhoso.

Sugerimos ao professor iniciar uma discussão que retome, em certa medida, o repertório que os alunos têm, em virtude da interação como universo do maravilhoso. Sugerimos as seguintes questões iniciais:

- Quais de vocês conhecem as histórias de O Gato de Botas, Aladim e Chapeuzinho Vermelho?

- De onde vocês conhecem esses personagens?

- Como vocês tiveram contato com essas histórias?

- Vocês sabem de onde essas narrativas vieram?

- Quando vocês estão assistindo a filmes/séries ou lendo alguma história como essas, acham esquisito um gato se comportar como uma pessoa ou um tapete voar por aí com uma pessoa sobre ele?

Professor, entendemos que a maioria dos alunos não apresentam estranhamento com os acontecimentos sobrenaturais nas narrativas fantásticas, pois têm um pacto de leitura bastante desenvolvido por meio dos letramentos que envolvem as narrativas maravilhosas, seja por meio de filmes e/ou livros aos quais tiveram acesso dentro e fora do espaço escolar.

Após a abordagem inicial da discussão, sugerimos ao professor entregar uma cópia dos textos conceituais abaixo e fazer a leitura com os alunos, explicando as questões.

"No início dos tempos, o maravilhoso foi a fonte misteriosa e privilegiada de onde nasceu a literatura. Desse maravilhoso nasceram personagens que possuem poderes sobrenaturais; deslocam-se, contrariando as leis da gravidade; [...] defrontam-se com as forças do Bem e do Mal, personificadas." (COELHO, 2000, p. 172);

"No caso do maravilhoso, os elementos sobrenaturais não provocam qualquer reação particular nas personagens. Os acontecimentos sobrenaturais aí não provocam qualquer surpresa." (TODOROV, p. 59-60) 
Se nas narrativas do gênero maravilhoso o sobrenatural não é questionado, pois faz parte das leis daquele mundo que as coisas aconteçam daquele modo, em outras narrativas, por outro lado, apresenta-se o mundo como o conhecemos, segundo suas leis naturais, e o sobrenatural irrompe, de forma a desestabilizar o modo como as coisas são. Nessas narrativas, questionamo-nos se o acontecimento de fato ocorreu ou se trata de um sonho, ilusão ou algo do gênero. A resposta é uma incerteza. Essas narrativas são chamadas de fantásticas e podem ser definidas conforme se lê abaixo:

"Somos transportados ao âmago do fantástico, quando, num mundo que é exatamente
o nosso, aquele que conhecemos, sem diáboas, sílfides nem vampiros, produz-se um
acontecimento que não pode ser explicado pelas leis deste mesmo mundo familiar.
Aquele que o percebe deve optar por uma das duas soluções possíveis; ou se trata de
uma ilusão dos sentidos, de um produto da imaginação e nesse caso as leis do mundo
continuam a ser o que são; ou então o acontecimento realmente ocorreu, é parte
integrante da realidade, mas nesse caso esta realidade é regida por leis desconhecidas
para nós." (TODOROV, 2008, p. 30)
"O fantástico ocorre nessa incerteza; ao escolher uma ou outra resposta, deixa-se o
fantástico para entrar num gênero vizinho, o estranho ou o maravilhoso. O fantástico é
a hesitação experimentada por um ser que só conhece as leis naturais, face a um
acontecimento aparentemente sobrenatural." (TODOROV, 2008, p. 31. Adaptado)

Sugerimos ao professor retomar alguns trechos da narrativa, para pontuar os momentos de hesitação e incerteza. Retome oralmente com os alunos:

O trecho 22, que narra sobre os olhos furados de Fabiojunio. (p. ;

O trecho 31, momento em que Simara se depara com as ruínas do antigo casarão;

Os trechos 34 e 35, quando Simara vê os túmulos do casal e do irmão;

O trecho 40, momento em que Simara vê a própria fotografia.

Na retomada a esses trechos, sugerimos ao professor questionar aos alunos como é possível explicar cada um dos acontecimentos destacados, segundo às leis naturais e segundo às leis sobrenaturais. O professor deve reforçar, neste momento, a impossibilidade de enquadrarmos tais acontecimentos em uma lógica "fechada". 
Sugerimos que o professor retome os trechos destacados abaixo para expor aos alunos dois "procedimentos de escritura" do gênero fantástico, conforme Todorov, a saber: o imperfeito e a modalização.

Trecho 10 - "Não sabia dizer direito o que era." (p. 10);

Trecho 15 - "Estava sozinho [...]. Parecia triste." (p. 11);

Trecho 20 - "parecia-Ihe mais evidente que havia algo muito estranho." (p.12);

Trecho 29 - "Talvez ainda possamos salvá-lo." (p.14);

Trecho 30 - "como se a terra tivesse sido amaldiçoada" (p. 15);

Trecho 31 - "era a casa da foto. Ou era a casa como teria sido" (p.15);

Trecho 33 - "Viu, [...], o que deveria ter sido a sala de jantar. (15)".

Após pedir que os alunos destaquem esses trechos, o docente deve questionar sobre a assertividade, clareza, objetividade e firmeza sobre o que se narra em cada um deles.

O professor pode explicar oralmente que os textos fantásticos fazem uso de certo tipo de escrita para gerar a hesitação e a incerteza no leitor. Por exemplo, no texto Aurélia de Nerval - "eu tinha a impressão de que a alma de meu antepassado estava naquele pássaro" - se fosse omitida a forma verbal "tinha", poderíamos dizer que se trataria de uma narrativa no âmbito do maravilhoso. O professor pode explicar que certos tempos verbais, como o pretérito imperfeito, e os modalizadores são duas formas que contribuem para gerar a ambiguidade dos fatos e a dúvida sobre a ocorrência deles.

O professor pode complementar brevemente que os modalizadores são elementos textuais que têm a função de modular o ponto de vista da narrativa; e que o pretérito imperfeito e o futuro do pretérito são dois tempos verbais que indicam a incerteza dos fatos, como, por exemplo, parecia, deveria ter sido, teria sido. Sobre o primeiro procedimento de escritura, o professor pode destacar que Castilho e Castilho (1993, p. 217) explicam sobre um tipo de modalização que eles chamam de "quase-asseverativo"; essa modalização envolve palavras, como, quase, talvez, possivelmente, entre outros. Sobre o segundo procedimento, o professor pode ressaltar, conforme Todorov (2008, p. 44) explica, que "o imperfeito introduz uma distância entre a personagem e o narrador, de tal modo que não conhecemos a posição deste último." 


\section{Etapa 4: - Avaliação}

A etapa de avaliação, neste caso, é um momento importante para que o professor possa medir quanto de ampliação de repertório literário no universo da literatura fantástica o aluno desenvolveu após a experiência da leitura com esse tipo de narrativa. Para a etapa de avaliação, sugerimos ao professor desenvolver alguma atividade do tipo:

- O docente poderia selecionar outro conto que, do mesmo modo, esteja no âmbito do fantásticomaravilhoso, para que os alunos leiam e pontuem no texto os momentos em que se instaura a hesitação;

- O educador poderia selecionar três contos: um de viés fantástico-maravilhoso e os outros dois nitidamente de viés maravilhoso; faria a divisão em grupos e entregaria as narrativas. O papel dos alunos nos grupos seria o de ler os contos entre si para dizer qual deles é o que estaria na lógica de uma narrativa fantástica dentro do viés estudado, ou seja, do fantástico-maravilhoso. Após isso, abre-se a discussão coletiva para que os grupos apresentem os argumentos que confirmem a categorização de cada conto;

- O professor poderia montar grupos de cinco alunos, entregar um conto diferente para cada grupo e pedir que os alunos façam a leitura da história para a turma e exponham qual a perspectiva que a narrativa apresenta dentro do aspecto fantástico. 


\section{REFERÊNCIAS BIBLIOGRÁFICAS}

AGUIAR, Flávio. Literatura, cinema e televisão. São Paulo: Senac, Itaú Cultural, 2003.

AGUIAR, Vera T. "O saldo da leitura". In: DALVI, M. A.; REZENDE, N. L. de; FALEIROS, R. J. Leitura de literatura na escola. 1 ed. São Paulo: Parábola Editorial, 2013. P. 153-161.

BARROS, Fernando M., COLUCCI, Luciana, FRANÇA, Júlio, (Orgs.). "Apresentação”. In: O medo como prazer estético: (re)leituras do gótico literário. Rio de Janeiro: Dialogarts, 2015.

BORTONI-RICARDO, S. M. O professor pesquisador: introdução à pesquisa qualitativa. São Paulo: Parábola, 2008.

BRASIL. Portaria $\mathrm{n}^{\circ}$ 343, de 17 de março de 2020. Disponível em: http://www.planalto.gov.br/CCIVIL 03/Portaria/PRT/Portaria\%20n\%C2\%BA\%20343-20-mec.htm.

Acessado em 18 de dezembro de 2020

BRASIL. Parâmetros Curriculares Nacionais (PCNs). Língua Portuguesa. Ensino Fundamental. Brasília: MEC/SEF, 1998. Ministério da Educação. Base Nacional Comum Curricular - BNCC. Brasília, DF, 2017.

Carta dos Direitos Fundamentais da União Europeia. Disponível em: http://www.direitoshumanos.usp.br/index.php/Documentos-n\%C3\%A3o-Inseridos-nas-

Delibera\%C3\%A7\%C3\%B5es-da-ONU/carta-dos-direitos-fundamentais.html Acessado em 03 nov. 2020.

CASTILHO, A. T.; CASTILHO, C. M. M. de. Advérbios Modalizadores. In: ILARI, Rodolfo (org.) Gramática do Português Falado. Vol. II: Níveis de Análise Lingüística. $2^{a}$ Edição. Campinas: Editora da UNICAMP, 1993.

COELHO, N. N. Literatura Infantil: teoria, análise e didática. São Paulo: Ática, 2000.

COLOMER, T. Andar entre Livros. São Paulo. Global. 2007.

CORRÊA, Hércules T. "Letramento literário na escola". In: CYRANKA, Lucia F. M e MAGALHÃES, Tânia G.(orgs). Ensino de linguagem: perspectivas teóricas e práticas pedagógicas. Juiz de Fora: Ed. UFJF, 2016. P. 55-75.

COSSON, R. \& PAULINO, G. "Letramento literário: para viver a literatura dentro e fora da escola". In: ZIBERMAN, R; ROSING, T. Escola e leitura: velha crise, novas alternativas. São Paulo: Global Editora, 2009. P. 61-79.

DALVI, Maria A. "Literatura na escola: propostas didático-metodológicas". In: DALVI, M. A.; REZENDE, N. L. de; FALEIROS, R. J. Leitura de literatura na escola. 1 ed. São Paulo: Parábola Editorial, 2013.P. 67-97.

DONALISIO\& NAPIMOGA\& FREITAS. Análise da gravidade da pandemia de Covid-19. Epidemiol. Serv. Saúde 29 (2) 06 Abr 2020. Disponível em: https://doi.org/10.5123/S167949742020000200008. Acessado em 01 de janeiro de 2021. 
Experimento acelera legislação anticlone. Folha de São Paulo, São Paulo, 27 de nov. 2001. Disponível em: https://www1.folha.uol.com.br/fsp/ciencia/fe2711200101.htm Acessado em: 15 out. 2020.

FAGUNDES, Tatiana Bezerra. Os conceitos de professor pesquisador e professor reflexivo: perspectivas do trabalho docente. Revista brasileira de educação, v. 21, n. 65, abr./jun. 2016, p. 281-298.

FARIA, Carmen R. S. M. de e ROMERO, Luiz C. P. "Clonagem humana”. Senatus. Brasília, v. 2, n. 1, dez. 2002, p. $\quad$ 16-23. Disponível em: https://www2.senado.leg.br/bdsf/bitstream/handle/id/70291/0657212\%20Clonagem\%20Humana.p df? sequence=3\&isAllowed=y Acesso em: 12 out. 2020. Acessado em 03 nov. 2020

GARCÍA, Flavio. "A construção insólita de categorias da narrativa como estratégia necessária e essencial à literatura fantástica". In: ESTEVES, Antonio R.; RAPUCCI, Cleide Antonia (Orgs.). Vertentes do Insólito e do Fantástico: leituras. Rio de Janeiro: Dialogarts, 2017. P. 111-133.

LETRAMENTO. In: Glossário do Ceale. Termos de alfabetização, leitura e escrita para educadores. Disponível em:

http://www.ceale.fae.ufmg.br/app/webroot/glossarioceale/verbetes/letramento.

LOVECRAFT, H.P. O horror sobrenatural em literatura. São Paulo: Iluminuras, 2020.

ISER, W. "O repertório". In: O ato de leitura: uma teoria do efeito estético. Tradução: Johannes Kretschmer. São Paulo: Ed. 34, 1996, p. $101-157$.

MINAS GERAIS (Estado). Resolução no 474, de 08 de maio de 2020. Disponível em: https://cee.educacao.mg.gov.br/index.php/legislacao/resolucoes/send/5-2020/12965-resolucao-

cee-474-reorganizacao-calendario-escolar-final-pandemia-covid-19. Acessado em 18 de dezembro de 2020

NÓVOA, Antônio. O professor pesquisador e reflexivo. Entrevista concedida em 13 de setembro de 2001. Disponível em: http://www.tvebrasil.com.br/salto/entrevistas/antoni o_novoa.htm. Acessado em 15 de janeiro de 2019

ONU aprova declaração contra clonagem humana. Estadão, São Paulo, 08 de mar. de 2005. Disponível em: https://ciencia.estadao.com.br/noticias/geral,onu-aprova-declaracao-contraclonagem-humana,20050308p210 Acessado em: 15 out. 2020.

PAULINO, Graça. Letramento Literário Por Vielas e Alamedas. Revista da FACED, Belo Horizonte, Edição no 05, 2001, p. 117 - 125.

PELLEGRINI, Tânia, JOHNSON, Randal, XAVIER, Ismael, GUIMARÃES, Hélio e

PINHEIRO, Marta Passos. Letramento literário na escola: um estudo de práticas de leitura literária na formação da "comunidade de leitores". Tese de Doutorado, UFMG, 2006.

PRADA, Oropeza, El discurso fantástico contemporáneo: tensión semântica y efecto estético, Semiosis, II, núm. 3, 2006 p. 53-76. 
RAMOS, Ana V. G. F. F. e RIBEIRO, Luiz G. G. "A sociedade de risco, a clonagem de embrião humano e o direito penal: necessidade de revisão do art. 26 da lei no 11.105/05?". Publica Direito (plataforma). Disponível em: http://www.publicadireito.com.br/artigos/?cod=f1cf2a082126bf02. Acessado em 10 out. 2020.

REZENDE, Neide L. "O ensino de literatura e a leitura literária". In: DALVI, M. A.; REZENDE, N. L. de; FALEIROS, R. J. Leitura de literatura na escola. 1 ed. São Paulo: Parábola Editorial, 2013. P. 99-112.

SOARES, Magda. "A escolarização da literatura infantil e juvenil". In: Escolarização da Leitura Literária: O Jogo do Livro Infantil e Juvenil. Belo Horizonte: Autêntica, 2011. P. 17-48.

STRAUSZ, Rosa Amanda. "Crianças à venda. Tratar aqui". In: STRAUSZ, Rosa Amanda. Sete ossos e uma maldição. São Paulo: Global, 2013. P. 7-17.

THIOLLENT, Michel. Metodologia da pesquisa-ação. 2.ed. São Paulo: Cortez, 1986.

TODOROV, T. "Definição do fantástico". In. Introdução à literatura fantástica. São Paulo: Perspectiva, 2008. P. 29-63.

TRIPP, David. Pesquisa-ação: uma introdução metodológica. Trad. de Lólio Lourenço de Oliveira. Educação e Pesquisa. São Paulo, v. 31, n. 3, p 443-466, set./dez. 2005.

TUCK me in. Direção de Ignácio Rodó. 2014. Publicado na plataforma Vimeo, no canal de Ignácio Rodó. Disponível em: https://vimeo.com/97259197. Acesso em 20 dez. 2020.

Direção de Ignácio Rodó. 2014. Publicado pela plataforma Youtube, no canal de Luiz Fernando Alves. Disponível em: https://www.youtube.com/watch?v=NoLrgU82HAs Acesso em 08 abr. 2018.

ZAPPONE, M. H. Y. Modelos de letramento literário e ensino da literatura: problemas e perspectivas. Teoria e Prática da Educação, v. 03, p. 47-62, 2007.

ZATZ, Mayana. Clonagem humana: conhecer para opinar. In: Pesquisa Fapesp. São Paulo, mar. de 2002. Disponível em https://revistapesquisa.fapesp.br/clonagem-humana-conhecer-paraopinar-2/ Acesso em 20 de dezembro de 2020. 
VOLTAR PARA O INÍCIO 